\title{
Improving Toxicity Assessment of Pesticide Mixtures: The Use of Polar Passive Sampling Devices Extracts in Microalgae Toxicity Tests
}

\author{
Sandra Kim Tiam ${ }^{* \dagger}$, Vincent Fauvelle ${ }^{\dagger}$, Soizic Morin and Nicolas Mazzella \\ Institut National de Recherche en Sciences et Technologies pour l'Environnement et l'Agriculture, UR EABX, Cestas, France
}

OPEN ACCESS

Edited by:

George Tsiamis,

University of Patras, Greece

Reviewed by:

Prasun Ray,

Samuel Roberts Noble Foundation,

USA

Michael Kevin Watters,

Valparaiso University, USA

*Correspondence:

Sandra Kim Tiam

sandra.kimtiam@gmail.com

${ }^{\dagger}$ Present Address:

Sandra Kim Tiam,

Centre Eau Terre Environnement, Institut National de la Recherche

Scientifique, Québec, Canada;

Vincent Fauvelle,

National Research Centre for

Environmental Toxicology (Entox),

University of Queensland, Coopers Plains, Australia

Specialty section:

This article was submitted to

Systems Microbiology

a section of the journal

Frontiers in Microbiology

Received: 27 May 2016

Accepted: 23 August 2016 Published: 09 September 2016

Citation:

Kim Tiam S, Fauvelle V, Morin S and Mazzella N (2016) Improving Toxicity Assessment of Pesticide Mixtures:

The Use of Polar Passive Sampling

Devices Extracts in Microalgae Toxicity

Tests. Front. Microbiol. 7:1388

doi: 10.3389/fmicb.2016.01388
Complexity of contaminants exposure needs to be taking in account for an appropriate evaluation of risks related to mixtures of pesticides released in the ecosystems. Toxicity assessment of such mixtures can be made through a variety of toxicity tests reflecting different level of biological complexity. This paper reviews the recent developments of passive sampling techniques for polar compounds, especially Polar Organic Chemical Integrative Samplers (POCIS) and Chemcatcher ${ }^{\circledR}$ and the principal assessment techniques using microalgae in laboratory experiments. The progresses permitted by the coupled use of such passive samplers and ecotoxicology testing as well as their limitations are presented. Case studies combining passive sampling devices (PSD) extracts and toxicity assessment toward microorganisms at different biological scales from single organisms to communities level are presented. These case studies, respectively, aimed (i) at characterizing the "toxic potential" of waters using dose-response curves, and (ii) at performing microcosm experiments with increased environmental realism in the toxicant exposure in term of cocktail composition and concentration. Finally perspectives and limitations of such approaches for future applications in the area of environmental risk assessment are discussed.

Keywords: POCIS, Chemcatcher, passive samplers, biofilms, low dose, PICT, environmental risk assessment

\section{INTRODUCTION}

Aquatic organisms are exposed to a large variety of natural and anthropogenic stressors. Environmental conditions such as temperature, nutrients, light, flow, are ever changing, as well as chemical contaminants. Rivers are contaminated by complex mixtures of organic and inorganic substances, generally present at low concentrations. Risk assessment thus requires consider this complexity in exposure conditions (Chèvre and Gregorio, 2013).

Recent developments of passive sampling techniques allowed, (i) to better consider the diversity of co-occurring substances in the environment, (ii) to lower their detection limits, and (iii) to focus on the freely dissolved fraction instead of the total amount of contaminants, which is more comparable to the in situ bioavailability. These advantages of passive sampling compared to spot sampling relied on the capacity of the device to accumulate contaminants over a defined period of time. They thus provide a more complete panorama of the contamination. Among passive sampling devices (PSDs), Polar Organic Chemical Integrative Samplers (POCIS) and Chemcatchers ${ }^{\circledR}$ are used to quantify time-weighted-average concentrations of organic substances 
in aquatic environments, especially for hydrophilic pesticides (see Alvarez et al., 2004). Depending on their configuration, both samplers are able to accumulate linearly dissolved polar contaminants over a period of time. Then, complex mixtures of polar organic compounds (e.g., pesticides, pharmaceuticals) can be extracted from these passive samplers to perform toxicity tests at different biological scales from single organisms to community levels.

Societal demand calls for increasing ecological relevance of ecotoxicological testing, in particular regarding the biological endpoints used (Artigas et al., 2012). Biofilms have been used in ecotoxicology because of their high degree of environmental relevance (Sabater et al., 2007). This community (composed of microalgae, bacteria, fungi, protozoa, etc.) integrates a higher amount of biological complexity than standardized tests using single model species or sub-cellular endpoints conventionally used in toxicity testing. Biofilm-based ecotoxicology increases the predictive power of impacts at the ecosystem scale, compared to the extrapolation of results disconnected from the natural complexity (diversity of organisms and of their relations). These communities are used successfully in ecotoxicology, in the laboratory or in situ, to assess impacts of diverse contaminants (e.g., Guasch et al., 2012). Laboratory experiments with biofilms involve single substances or simple (binary, ternary) combinations. However, the determination of the ecotoxicity of complex mixtures of toxicants could hardly be achieved this way, given the multiplicity of possible cocktails (in terms of composition, and concentrations), preventing to test all the combinations likely to be found in situ.

\section{Passive Sampling}

Evaluation of water quality relative to chemical substances concentration is generally based on spot sampling (2000/60/EC). This type of sampling is quick, easy to realize and relatively low cost but the data obtained are limited regarding temporal representativeness and detection limits. For example, in the case of peaks of contaminants occurring within hours, spot sampling will not offer a good picture of water contamination. Limitations of spot sampling strategies also concern the detection limit of compounds present under the ng/L. An interesting option in order to compensate for these limitations can be found in passive sampling.

\section{History of PSDs Development}

History of passive sampling starts early 70's with the development of devices able to accumulate atmospheric pollutants by diffusion (Palmes and Gunnison, 1973) or permeation (Reiszner and West, 1973). Two decades by then, the first passive samplers adapted for aquatic environments appear with the SPMD (Semipermeable Membrane Device; Huckins et al., 1990) used for sampling of non-polar organic compounds and then the DGT (Diffusive Gradient in Thin-film; Davison and Zhang, 1994) specific for inorganic contaminants such as metals and phosphates. By then, a considerable number of passive samplers have been developed for medium polar contaminants: MESCO (Membrane-Enclosed Silicone Collector; Paschke et al., 2006), LDPE (Low-Density Polyethylene; Müller et al., 2001), SR (Silicone Rubber; Rusina et al., 2010), Chemcatcher ${ }^{\circledR}$ (Kingston et al., 2000), POCIS (Polar Organic Chemical Integrative Sampler; Alvarez et al., 2004). Several recent developments reported the adaptation of POCIS and DGT for the sampling of highly polar compounds such as antibiotics (e.g., sulfamethoxazole), perfluorinated chemicals, and pesticides (e.g., glyphosate, 2,4-D) (Fauvelle et al., 2012, 2015; Chen et al., 2013; Kaserzon et al., 2014a).

\section{Principles of Passive Sampling}

The general principles of passive sampling have been reviewed exhaustively by Vrana et al. (2005). Briefly, PSDs can be compared to a standardized compartment introduced in the water column (or other media such as sediment, soil, etc.), able to accumulate the contaminants of interest. The flux of contaminants from water to the sample is theoretically governed by chemical diffusion, and is assumed to follow a first-order kinetic composed of (i) an initial integrative phase, and (ii) a later equilibrium or saturation of the receiving phase. During the integrative phase, the receiving phase of the sampler is considered as an infinite sink, ensuring a difference of chemical activity between both the water and the sampler receiving phase; and the time weighted averaged concentration $C_{w}$ in water (ng/L) can be deduced from $N_{s}$ the amount of analytes measured in the sampler (ng) as presented in the equation:

$$
C_{W}=\frac{N_{s}}{R_{s} \times t}
$$

where $R_{s}$ the sampling rate constant of the analyte from the water to the sampler $(\mathrm{L} / \mathrm{d})$, and $t$ the exposure duration (days). Obviously, the back calculation of $C_{w}$ implies the prior determination of $R_{s}$ under controlled conditions of $C_{w}$, temperature, flow rate, etc.

\section{Passive Sampling: For a Better Characterization of Environmental Contaminations}

PSDs propose several advantages compared to spot sampling inherent to their accumulation properties. First, they give a more realistic representation of environmental contamination by integrating the contamination during a determinate period of time while spot sampling only gives a picture of the contamination at the precise sampling time. This characteristic is critical considering environments where contaminations are transiting, like in rivers where the duration of the contamination peaks can be measured in hours. Indeed the analysis of the compounds extracted from a passive sampler exposed in the field will give a better estimation of water contamination during this period than one analysis performed on grab water sampled one time during the typical 2 weeks passive sampler exposure. Second, passive sampling allows a lowering of detection limits since in situ preconcentration rates (tenth of a liter to several liters per day of exposure) are much higher than that generally applied during a conventional solid phase extraction procedure for a spot sample (Allan et al., 2006; Harman et al., 2012; Morin et al., 2012a). This gain in detection limit is particularly relevant when considering chemical substances that the environmental quality standards (EQS) values defined by the UE Water framework Directive (2000/60/EC) are below the ng/L threshold [e.g., 
$0.17 \mathrm{ng} / \mathrm{L}$ for benzo(a)pyrene and $0.08 \mathrm{ng} / \mathrm{L}$ for the pesticide cypermethrin]. Third, as passive samplers are able to accumulate specifically the free dissolved fraction of the target substances, they are more likely to catch only the bioavailable fraction of contaminants (Harman et al., 2012). In the case of polar substances, such fraction can be achieved by filtration of the sample at a given cutoff (generally from 0.1 to $0.45 \mu \mathrm{m}$ ), although equilibrium between dissolve and particulate phases could be altered during sample treatment and storage steps (Allan et al., 2006). In the case of ionic substances, including both inorganic and organic species (e.g., metals, phosphates, some antibiotics, or ionic pesticides like glyphosate), speciation has also to be taken into account, since complexation tends to inactivate their toxicity (Tsui et al., 2005; Zhou et al., 2013). This paper only reviews the passive samplers which were used for subsequent biotesting (i.e., POCIS and Chemcatcher ${ }^{\circledR}$ ). They were chosen because of their wide spectrum and high accumulation capacity. A table summarizes in a non-exhaustive way their performances for the sampling of various classes of polar pesticides (Table 1).

\section{Passive Samplers for Polar Pesticides}

\section{The polar organic chemical integrative sampler (POCIS)}

POCIS has been developed at the beginning of the 2000's because of the lack of passive samplers for polar organic compounds (Alvarez, 1999; Alvarez et al., 2004). It is to date one of the mostly used polar PSD, and some papers review extensively their application (Harman et al., 2012; Morin et al., 2012a). POCISs are made of a microporous sorbent phase sequestered between two membranes of polyethersulfone (PES, usually pores diameter $0.1 \mu \mathrm{m}$ ) and maintained by two stainless steel rings. It exists under two commercial configurations "pesticides" and "pharmaceutical" that differ from the nature of their sorbent. Besides their denomination, « pharmaceutical POCIS $\gg$ revealed to be more adapted to the sampling of a larger range of polar pesticides, i.e., for compounds having a $\log$ $K_{o w}$ between 1 and 4 (Mazzella et al., 2007). For biotesting applications, performance reference compounds (PRCs) are not used to correct from environmental exposure conditions, since they could induce a high baseline toxicity (Pesce et al., 2011).

\section{The Chemcatcher ${ }^{\circledR}$}

Chemcatcher ${ }^{\circledR}$ was first developed for non-polar contaminants (Kingston et al., 2000), and was then adapted for metals (Björklund Persson et al., 2001), organo metallic compounds (Aguilar-Martínez et al., 2011), and a wide range of polar contaminants (Moschet et al., 2015). It was the object of recent and extensive reviews (Charriau et al., 2016; Lissalde et al., 2016). Briefly, its polar configuration consists of a one-side opening housing (exposure area between 14.5 and $17.5 \mathrm{~cm}^{2}$ depending on the evoluting design) that includes a Empore disk receiving phase (C18 or SDB-XC or SDB-RPS) and an optional membrane (PES 0.1-0.45 $\mu \mathrm{m}$ pore size). Chemcatcher ${ }^{\circledR}$ thus allows many different combinations, with the additional advantage to have a stationary receiving phase which increase theoretically the reproducibility of the data compared to the POCIS. C18 and SDB-XC (styrenedivinylbenzene exchange) are adapted for the sampling of medium polar compounds (reversed phase sorbent), whereas SDB-RPS (styrenedivinylbenzene reverse phase sulfonate) is used for highly polar compounds (log $K_{o w}$ down to -2 approximately). Chemcatcher ${ }^{\circledR}$ procedure includes a conditioning step of the Empore disks before exposure (usually methanol and water), which constitutes a practical drawback compared to the POCIS. The addition of a PES membrane induces a decrease of the overall mass transfert coefficient of the analytes, and thus decreases their sampling rates as well, in order to reach a longer field exposure. As for the POCIS, PRC approach was investigated (Camilleri et al., 2012) but not implemented for biotesting achievements (Shaw et al., 2009).

\section{Assessment Techniques in Microalgae Laboratory Experiments}

Ecotoxicology was defined by Truhaut (1977) as "the branch of toxicology concerned with the study of toxic effects, caused by natural and synthetic pollutants, to the constituents of ecosystems, animals (including humans), vegetable, and microbial, in an integrated context." In ecotoxicology, lethal, and sub-lethal effects can be distinguished. Studies dealing with microalgae in ecotoxicology concern sub-lethal effects, defined as effects occurring at concentrations or doses below those producing direct somatic death (Rand and Petrocelli, 1985). We will present here the two main types of laboratory experiments that are used in order to assess the sub-lethal effects of toxicants on microalgae. These two types of laboratory experiments differ in term of concentrations of toxicant applied and exposure duration. In the first case, the effects of toxicants at high concentrations are assessed during a short time of exposure (typically $96 \mathrm{~h}$ ) using the dose-response approach. In the second case, microalgae are exposed to concentration of toxicants closed to environmental concentrations for a longer duration (generally more than 1 week).

\section{Evaluation of the Effects of Toxicant at High Concentration}

\section{Dose-response approach}

With the dose-response approach (Bruce, 1985, 1987), individuals are exposed to increasing concentrations of toxicant in order to characterize the toxicity of the studied compounds. The endpoint measured to evaluate effect can be any parameter likely to be affected by the toxicant (growth, reproduction, behavior, development etc.). The endpoint measurement for each exposure concentration allowed constructing a sigmoidal dose-response curve (Figure 1). Several methods have been developed to analyse dose-response data (see review in Newman, 2009). Parameters characterizing the toxicity of the studied compound can be extracted from the dose-response curve. The most common been the half maximal Effective Concentration $\left(\mathrm{EC}_{50}\right)$ defined as the concentration inhibiting $50 \%$ of the studied parameter compared to the control group. More generally $\mathrm{EC}_{\mathrm{x}}$ can be calculated (concentration inhibiting $\mathrm{X} \%$ of the studied parameter compared to the control group). Other parameters like the No Observed Effect Concentration (NOEC) or the Lowest Observed Effect Concentration (LOEC) can be obtained. The NOEC is the highest concentration in a test without significant difference compared to the control and 
TABLE 1 | Sampling of different polar pesticides by different configurations of POCIS and Chemcatcher.

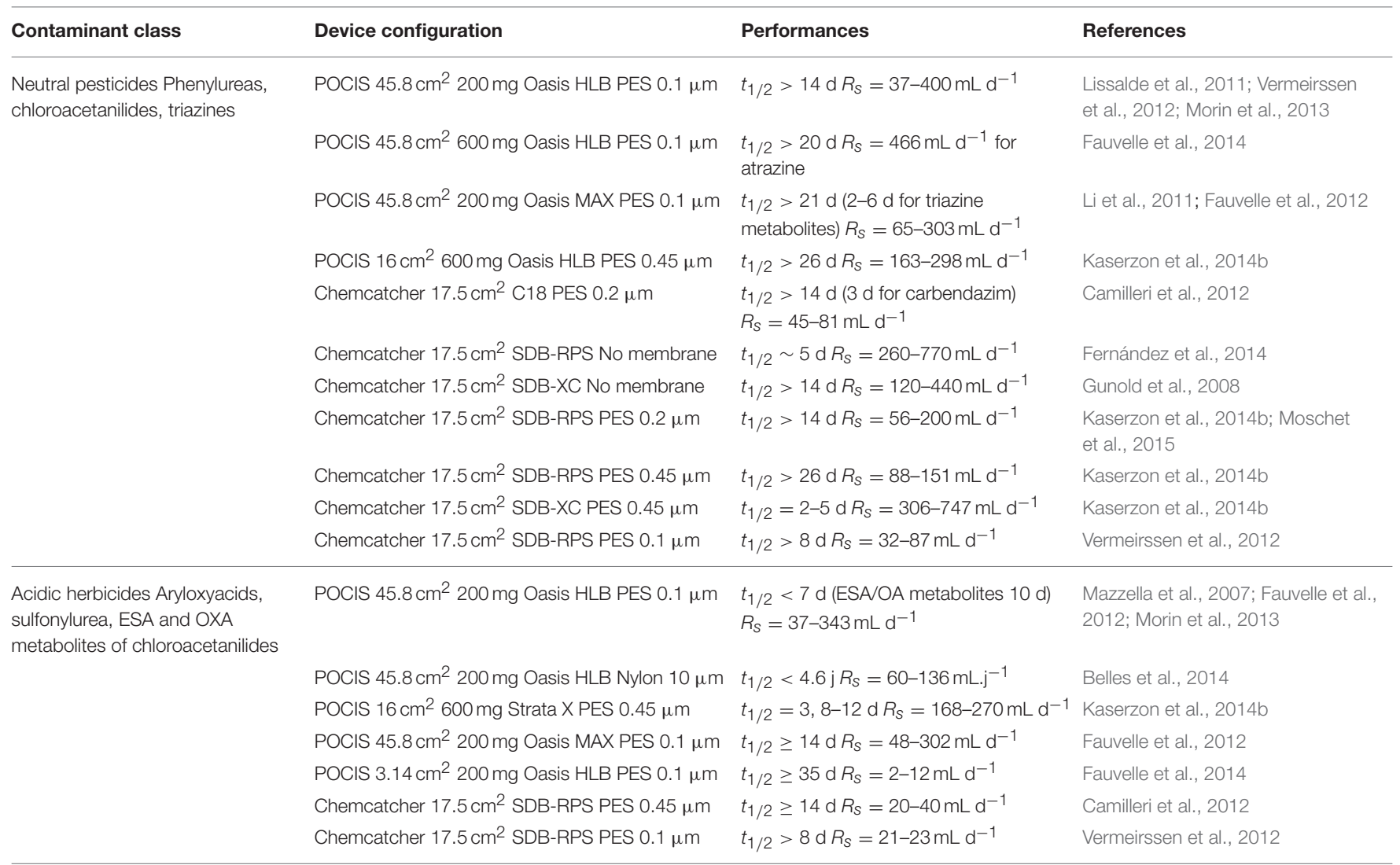

Device configuration is documented in terms of surface area, sorbent and membrane pore size. $t_{1 / 2}$, half-time to the equilibrium; $R_{S}$, sample rate; PES, polyethersulfone; SBD-RPS, Empore SDB-RPS disk; SBD-XC, Empore SDB-XC disk.

the LOEC is defined as the lowest concentration in a test with a significant effect compared to the control. An important shortcoming of NOEC and LOEC definitions has to be pointed out: NOEC and LOEC values are totally dependent of the exposure concentrations used in the dose-response toxicity testing (Newman, 2009).

\section{Dose-response with microalgae as biological model}

Dose-response toxicity tests have been used extensively in ecotoxicology in large part because of their ease of operation, rapidity, and low cost. Dose-response toxicity tests with microalgae can be realized at different organization levels from single species to community through simplified assemblages with a limited number of selected species.

The population growth inhibition bioassays on green algae (Scenedesmus subspicatus and Selenastrum capricornutum) or diatoms (Skeletonema costatum and Phaeodactylum tricornutum) are normalized bioassays for fresh and marine waters respectively, following the NF EN ISO 8692 (2012) and NF EN ISO 10253 (2006). Other single species toxicity tests have been used with cultures diatoms or green algae isolated from benthic or phytoplankton communities (Leboulanger et al., 2001; Fernández-Alba et al., 2002; Gatidou and Thomaidis, 2007;
Magnusson et al., 2008; Roubeix et al., 2011b; Larras et al., 2013; Kim Tiam et al., 2014a). Toxicity tests at the community level generally aimed at characterizing the community tolerance according to the PICT (Pollution Induced Community Tolerance, Blanck et al., 1988) concept (McClellan et al., 2008; Schmitt-Jansen and Altenburger, 2008; Montuelle et al., 2010; Pesce et al., 2010; Rotter et al., 2011; Tlili et al., 2011a,b; Larras et al., 2016).

\section{Evaluation of the Effects of Toxicant at Low Concentration}

Low dose and long term testing are more expensive, longer, and more complicated to realize compared to dose-response testing but offers a better realism regarding environmental exposure. Effect of various toxicant (pesticides, metals, bactericide, PCB) at concentrations closed to environmental contamination levels have been studied; on microcosms or channels systems; on biofilms (Pérès et al., 1996; Gold et al., 2003; Schmitt-Jansen and Altenburger, 2005; Pesce et al., 2006; Morin et al., 2008b, 2010, 2012b; Tlili et al., 2008, 2011c; Debenest et al., 2009; Ricart et al., 2009; Serra and Guasch, 2009; Corcoll et al., 2011; Roubeix et al., 2011a; Bonnineau et al., 2012; Barral-Fraga et al., 2016) and on phytoplanktonic assemblages (Fisher et al., 1974; Gustavson and Wängberg, 1995; Wallen, 1996; Seguin et al., 


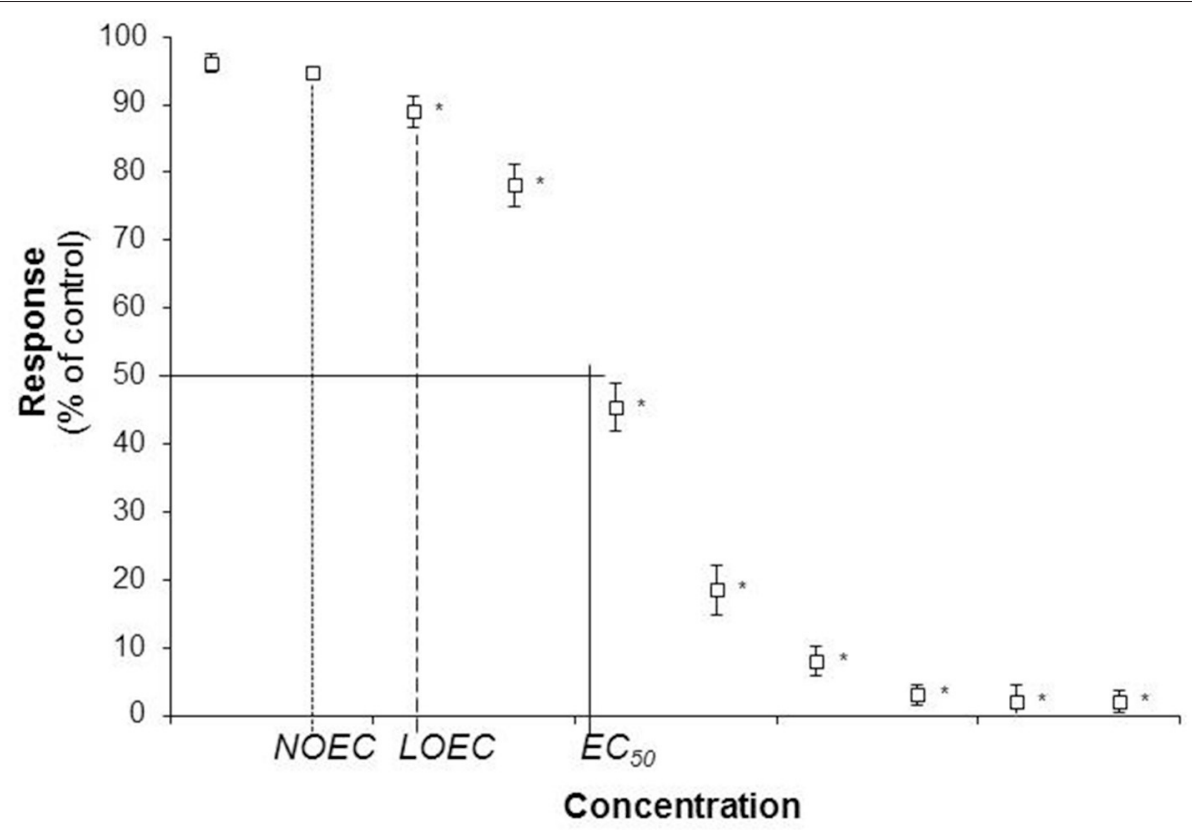

FIGURE 1 | Illustration of a dose-response curve with the half maximal Effective Concentration $\left(\mathrm{EC}_{50}\right)$, the No Observed Effect Concentration (NOEC), and the Lowest Observed Effect Concentration (LOEC). Stars illustrate statistical difference from control treatment.

2002; Echeveste et al., 2014; Pandey et al., 2015). Long-terms effects on phototrophic organisms can be evaluated regarding functional attributes, changes in biomass or effects on the community structure. As explained by Guasch et al. (2016) a big variety of endpoints can be chosen in order to evaluate these effects like photosynthesis and tolerance acquisition (functional attributes), chlorophyll concentration and algal density (changes in biomass), or algal groups, species composition, diatom cell size, teratoforms, and genetic diversity (community structure).

\section{The Mixture Issue: Theoretical Models and Limitations for Predicting Mixture Toxicity}

In environmental risk assessment, not taking mixture toxicity into account is likely to lead to hazard underestimation. The possible interactions between substances in combination were first studied in the 80 's in pharmacology, with the assessment of human drug interactions (Berenbaum, 1989). Then, the mixture issue was questioned in environmental studies, and ecotoxicological experiments were performed using binary or ternary combinations of toxicants (Roberts et al., 1990; Hickie et al., 1993; Parrott and Sprague, 1993). A large body of literature theoretical models were used to predict the joint effect of mixtures of chemicals based on their individual impacts and specific modes of action. The most commonly used models to predict mixture effects for similar- and dissimilaracting compounds are, respectively, Concentration Addition (CA, Loewe and Muischneck, 1926) and Independent Action (IA, Bliss, 1939). Both theories assume enhanced effects with increasing numbers of compounds and non-interaction between substances. Therefore, a deviation from the prediction indicates antagonism (weaker effects than predicted) or synergism (stronger effects).

However, these classifications were defined for assessing the impacts of simple mixtures (de Zwart and Posthuma, 2005), and their applicability to more complex mixtures requires to be more systematically tested. The need of characterizing the real impact of complex mixtures toward aquatic organisms, in laboratory experiments, could hardly be achieved using such simplified models, given the multitude of possible cocktails (in terms of composition and concentration), and of direct and indirect targets of the substances. Indeed, the large variety of chemical substances prevents from testing all the combinations likely to be found in situ. Additionally, ecotoxicological lack of knowledge on the modes of action of the substances (moreover depending on the target organism, and on the assessment endpoints, e.g., Cedergreen et al., 2007a,b) also limit the application of these models. Therefore, an alternative methodology for mixture toxicity assessment could be the direct use of realistic environmental mixtures.

\section{Use of PSD Extracts for Improvement of Mixture Toxicity Assessment}

As passive sampling techniques provide a more complete overview of the real contamination including unknown toxicants, PSD extracts were promising to apprehend the toxicity of environmental mixtures, since they opened perspectives for the use of these "field" extracts as complex contaminants in toxicity testing. PSD extracts present the major advantage that it may be used as a non a priori approach, regarding the composition of the mixture. Besides expected parent substances, PSD extracts 
TABLE 2 | Main advantages and limits of the use of polar passive sampler device (PSD) extracts in aquatic ecotoxicology.

Use of polar PSD extracts in aquatic ecotoxicology

\begin{tabular}{ll}
\hline Advantages & Limits \\
\hline High degree of representativity relative & Questions about the \\
to environmental contaminations & representativeness of the sampled \\
& fractions in relation to in situ exposure \\
& (concentration of compounds may be \\
& quite different from in situ \\
& concentrations due to different \\
& sampling rates)
\end{tabular}

Integration of contamination peaks

No notion of temporal succession of contaminant exposure

Integration of mixtures effects (additivity, synergism, antagonism)

No identification of substances responsible for toxicity

Possibility to use as a black box: Estimation of the global toxicity of the extract without a priori (toxicity of unidentified compounds is integrated)

High ecotoxicological relevance because mimics the uptake of xenobiotics by organisms

Case by case study

Only representative of the toxicity of the dissolved phase

Only sample contaminants in a determined range of polarity depending of the characteristics of the sorbent phase

Not taking in account the contamination due to the particulate fraction

Difficulty to standardize

may contain breakdown products, as well as any other nontargeted biologically active compounds. Moreover, in ecotoxicity testing, the use of PSD extracts does not require caring about possible interactions between substances (additivity, antagonism, synergism etc.), as the effects of the cocktail of contaminants is measured at a global scale, integrating potential interactions between the accumulated substances (Table 2).

\section{First Approaches Using PSD Extracts for Mixture Toxicity Testing}

Most of the time bioassays using POCIS and Chemcatcher ${ }^{\circledR}$ extracts have been dealing with mixtures present in sewage effluents (Petty et al., 2004; Vermeirssen et al., 2005; Liscio et al., 2009; Balaam et al., 2010) but also with cocktails present in waters subjected to agricultural (Matthiessen et al., 2006) or diverse anthropogenic pressures (Creusot et al., 2010; Jarosova et al., 2012; Bargar et al., 2013; Jálová et al., 2013). PSD extracts were used to determine the toxic potential of different aqueous matrices, in particular to target pharmaceuticals, and more specifically endocrine disruptors. To this end, toxicity was determined using standard tests such as the yeast estrogen screen (YES; Petty et al., 2004; Vermeirssen et al., 2005; Matthiessen et al., 2006; Liscio et al., 2009; Balaam et al., 2010; Bargar et al., 2013) or other reporter gene assays (Creusot et al., 2010; Jarosova et al., 2012; Jálová et al., 2013). This new coupling introduced more environmental realism to ecotoxicological tests, and improved the relative understanding of the effective toxicity of mixtures of pollutants in the aquatic environment.

\section{Predicting Phytotoxicity of Mixture with Single Species Testing}

First studies pairing passive sampling with bioassays in order to evaluate the photosynthetic effects of mixtures of contaminants were conducted using bioassays with microalgae as model organisms (Escher et al., 2005; Muller et al., 2007, 2008; Shaw et al., 2009; Vermeirssen et al., 2009, 2010). In these studies, mixture toxicity was evaluated by measuring photosynthetic efficiency after exposure to dilution series of PSD extracts (Table 3). The coupled use of PSD extracts and bioassays on microalgae allowed highlighting the phytotoxicity of the mixtures extracted from waters subjected to agricultural (Muller et al., 2008; Shaw et al., 2009), sewage effluent pressure (Muller et al., 2007; Vermeirssen et al., 2009, 2010), and diverse contaminations (Escher et al., 2006).

In these different studies, toxic equivalency concept was used to allow comparing the effect of PSD extracts to a reference compound (i.e., diuron). Diuron equivalent concentrations were calculated for the identified compounds in the extracts; then the toxicity measured in the bioassay and predicted based on chemical analysis results were compared in order to evaluate to which extent extract composition could explain the observed toxicity. In most of the cases, there was a general agreement between the measured and the predicted toxicity. For example, Vermeirssen et al. (2009) showed that six analyzed herbicides inhibitors of PSII correlated very well with toxicity measured in bioassays. Nevertheless, the observed toxicity was not always entirely explained by the chemical analytical results; this could results from the presence of unidentified toxic compounds in the extracts or the occurrence of synergic effects (Shaw et al., 2009; Vermeirssen et al., 2009).

Until now, toxicity testing performed on mixtures of herbicides extracted from different passive samplers have been bioassays on cultures of single microalgae species. Such bioassays have the advantages to be quite cheap and easy to implement but are poor in term of ecological realism. However, proper environmental risk assessment requires higher ecological realism, as pointed out by Artigas et al. (2012). To this end, the toxicity of PSD extracts was recently performed using natural communities likely to be exposed in their environment to these mixtures of chemicals.

\section{Application of Polar PSD Extracts in Mixture Toxicity Assessment Using Biofilms}

In order to increase ecological relevance in environmental risk assessment, it was proposed to realize ecotoxicological testing using PSD extracts on complex communities. In this purpose, two main experimental designs were used. Doseresponse curves were realized in order to evaluate community tolerance to mixture. Long-term effects of low dose of contaminants were assessed by long-term exposures (e.g., more than 1 week; Figure 2). In such toxicity testing, community tolerance is generally evaluated with functional parameters (e.g., photosynthesis, respiration, enzymatic activities...) whereas longterm effects of low dose of contaminants can be highlighted 
TABLE 3 | Studies assessing phytotoxicity of water using PSD extracts and ecotoxicological testing on microalgae.

\begin{tabular}{|c|c|c|c|c|c|}
\hline References & Study site & Landuse & Passive sampler & $\begin{array}{l}\text { Toxicity test } \\
\text { (duration) }\end{array}$ & Biological model \\
\hline Escher et al., 2006 & $\begin{array}{l}\text { Vicinity of the Noosa } \\
\text { National Park (Australia) }\end{array}$ & $\begin{array}{l}\text { Sewage effluent, } \\
\text { urban, domestic }\end{array}$ & $\begin{array}{l}\text { POS (passive sampler for } \\
\text { polar organic compounds) }\end{array}$ & $\begin{array}{l}\text { Dose-response } \\
(1-25 \mathrm{~h})\end{array}$ & Single species microalgae (n.a.) \\
\hline Muller et al., 2007 & n.a. & Sewage effluent & $\begin{array}{l}\text { POS (passive sampler for } \\
\text { polar organic compounds) }\end{array}$ & Dose-response (n.a.) & $\begin{array}{l}\text { Single species microalgae } \\
\text { (Phaeodactylum tricornutum) }\end{array}$ \\
\hline Muller et al., 2008 & $\begin{array}{l}\text { Brisbane River } \\
\text { (Australia) }\end{array}$ & Agriculture & $\begin{array}{l}\text { POS (passive sampler for } \\
\text { polar organic compounds) }\end{array}$ & $\begin{array}{l}\text { Dose-response (30 min } \\
\text { to } 2 \mathrm{~h} \text { ) }\end{array}$ & $\begin{array}{l}\text { Single species microalgae } \\
\text { (Phaeodactylum tricornutum and } \\
\text { Chlorella vulgaris) }\end{array}$ \\
\hline Shaw et al., 2009 & $\begin{array}{l}\text { Great Barrier Reef } \\
\text { (Australia) }\end{array}$ & Agriculture & Chemcatcher $^{\circledR}$ & Dose-response (2 h) & $\begin{array}{l}\text { Single species microalgae } \\
\text { (Phaeodactylum tricornutum) }\end{array}$ \\
\hline Vermeirssen et al., 2009 & $\begin{array}{l}\text { Northern part of } \\
\text { Switzerland }\end{array}$ & Sewage effluent & Chemcatcher $^{\circledR}$ & Dose-response (2 h) & $\begin{array}{l}\text { Single species microalgae } \\
\text { (Pseudokirchneriella subcapitata) }\end{array}$ \\
\hline Vermeirssen et al., 2010 & n.a & Sewage effluent & POCIS & Dose-response (2 h) & $\begin{array}{l}\text { Single species microalgae } \\
\text { (Pseudokirchneriella subcapitata) }\end{array}$ \\
\hline Booij et al., 2014 & $\begin{array}{l}\text { The Dutch estuarine and } \\
\text { coastal waters }\end{array}$ & Distinct landuse & POCIS & Dose-response (4.5 h) & $\begin{array}{l}\text { Single species microalgae } \\
\text { (Dunaliella tertiolecta) }\end{array}$ \\
\hline Kim Tiam et al., 2014b & Morcille River (France) & Vineyard & POCIS & $\begin{array}{l}\text { Dose-response }(24 \mathrm{~h}) \\
\text { and low dose exposure } \\
\text { (13 days) }\end{array}$ & Biofilms \\
\hline Kim Tiam et al., 2015 & Trec River (France) & $\begin{array}{l}\text { Growing cereal } \\
\text { crops }\end{array}$ & POCIS & $\begin{array}{l}\text { Low dose exposure } \\
\text { (14 days) }\end{array}$ & Biofilms \\
\hline Foulquier et al., 2015 & Morcille River (France) & Vineyard & POCIS & $\begin{array}{l}\text { Dose-response (30 } \mathrm{min} \\
\text { to } 3 \mathrm{~h} \text { ) }\end{array}$ & Biofilms \\
\hline
\end{tabular}

Study site, landuse, passive sampler, toxicity testing duration and biological model used in the studies are documented. n.a.: non available in the reference.

studying parameters related to community structure (e.g., taxonomic composition, biomass...).

POCIS extracts were used to assess the impacts of environmental pesticide mixtures with ecologically relevant bioassays with biofilms (Pesce et al., 2011; Morin et al., 2012c; Kim Tiam et al., 2014b). Toxicity testing of pesticide extracted from POCIS was recently performed on biofilms originated from different French rivers subjected to agricultural pressure (Table 4). Biofilms are communities composed by diverse microorganisms (microalgae, bacteria, fungi, etc.) embedded in an exo-polysaccharid (EPS) matrix. They are involved in major processes in water ecosystems functioning, in particular in primary production and organic matter processing. Pesce et al. (2009), besides, evidenced potential role of aquatic microbes in the degradation of pesticide compounds. The biological complexity of biofilms confer them a capacity of response to contaminants that depends on the kind of substances, their concentrations, their modes of actions (that may target, directly or indirectly, one or more of the diverse components of the biofilms), and the duration of exposure. The complementary endpoints available at different scales of biological organization allow to assess distinctly between short-term impacts of contaminants (early visible on functional endpoints) and long-term impairment (visible after long-term exposure on community structure (Sabater et al., 2007). In the same line Escher et al. (2005) proposed the use of a multi-endpoint toolbox to better assess the hazard of toxic compounds, by combining non-specific (or narcotic) and specific endpoints.

Ecotoxicity assessment combining mixture toxicity POCIS extracts (PE) and biofilms as "target organisms" is particularly relevant, given the fact that POCIS accumulate pesticides, in particular herbicides (Table 1), and that biofilms are principally composed of autotrophic organisms. Biological toxicity testing requires large amounts of contaminants. POCIS where shown to accumulate sufficient amount of contaminants to run such tests (e.g., $287 \mathrm{~mL} /$ day for acetochlor ESA for $600 \mathrm{mg}$ of sorbent, Fauvelle et al., 2014).

\section{Community tolerance to mixture}

Risk assessment of mixtures has mainly been performed through dose-response bioassays. In particular, PE were applied at increasing mixture concentrations to perform PICT approaches. The PICT principle relies on the hypothesis that when a community is exposed to a toxicant the abundance of sensitive organisms to this toxicant will decrease in favor of less sensitive organisms. This shift in community structure is leading to a higher tolerance of the new formed community compared to the previous one. In such approach, community tolerance is generally assessed with dose-response curves. The works based on the PICT concept, using PE considered as a "blackbox" of contaminants, allowed to highlight previous exposure of the biofilms, or not, to these cocktails. The ecological significance 


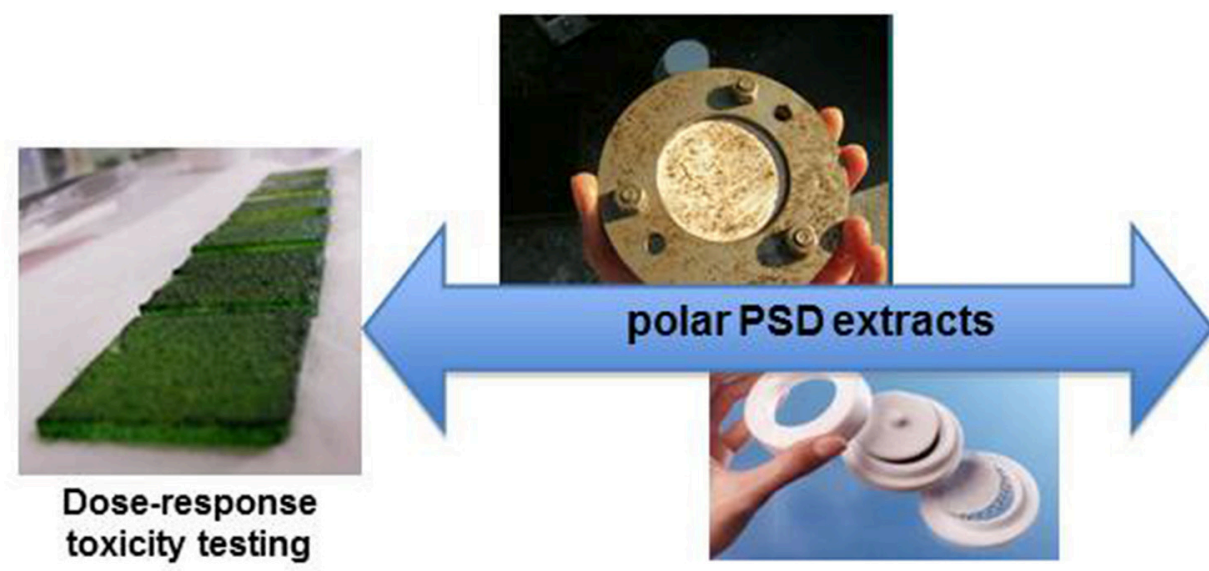

Duration: hours to days

Effect studied:

community tolerance to mixture of contaminants

$$
\begin{aligned}
& \text { Toxicity endpoint: } \\
& \text { functional } \\
& \text { (e.g. photosynthesis, } \\
& \text { respiration, enzymatic } \\
& \text { activities...) }
\end{aligned}
$$

\author{
Duration: \\ days to weeks \\ Effect studied: \\ long-term effects of low dose \\ of contaminants \\ Toxicity endpoint: \\ structural \\ (e.g. taxonomic composition, \\ biomass...)
}

FIGURE 2 | Duration, effects studied and examples of endpoints used in toxicity testing using polar passive sampler device (PSD) extracts and biofilms.

of combined PICT and PE approaches proved to be relevant, for biofilms sampled from rivers presenting different contamination profiles in term of concentrations and/or nature of compounds detected (Pesce et al., 2011; Morin et al., 2012c; Kim Tiam et al., 2014b; Foulquier et al., 2015). The PICT responses of field biofilms were compared in three study sites subjected to distinct kinds of agricultural pressure (increasing vineyard occupation from upstream to downstream in Morcille river, distinct land use along the Ruiné river and growing cereal crops at the Trec river; Table 4). Dose-response curves performed with PE sampled at the downstream (Ruiné and Morcille) or contaminated (Trec) site allowed to evidence differences in the sensitivity to PE mixtures depending on the origin of the biofilms. Apart from Foulquier et al. (2015), significant higher tolerance was measured for biofilms originated from the most contaminated site (noted contaminated for Trec river and downstream for Morcille river in Table 4). These results confirmed the relevance of using PE as "blackbox" complex contaminants to reveal biofilm exposure history. Notably, the mixtures were generally dominated by breakdown products. The ecotoxicity of pesticides metabolites is less studied than that of their parent compound, although they may be much more toxic (Sinclair and Boxall, 2003). In particular, norflurazon desmethyl was shown to inhibit biofilm photosynthesis at concentrations much lower than norflurazon (Kim Tiam et al., 2014a).

With the combined PICT and PE approaches, previous biofilm pesticide exposure can be evidenced by the measure of biofilm tolerance to the pesticide mixture. Tolerance (measured in term of ECx, LOEC...) can thus be easily compared for biofilms originated from different sites. However, in these approaches it is difficult to compare results from different studies.

\section{Impacts of low dose and long-term exposure}

With the success of PE use for dose-response bioassays on biofilms, new perspectives were opened for further applications, including their use as composite contaminants for low dose and long-term exposure in laboratory experiments. The use of diluted PE in long-term exposure experiments is particularly relevant to empirically demonstrate the potential toxicity of environmental cocktails, as they occur in rivers. Demonstrating the toxicity, or not, of $\mathrm{PE}$ at low (environmentally realistic) dose is required for a renewed risk assessment and the revision of current quality standards taking mixtures into account (as previously recommended by Chèvre et al., 2006).

First attempts provided evidence that PE could be used for those purposes (Morin et al., 2012c), but required experimental improvements. Fluvial biofilm was exposed in artificial channels 


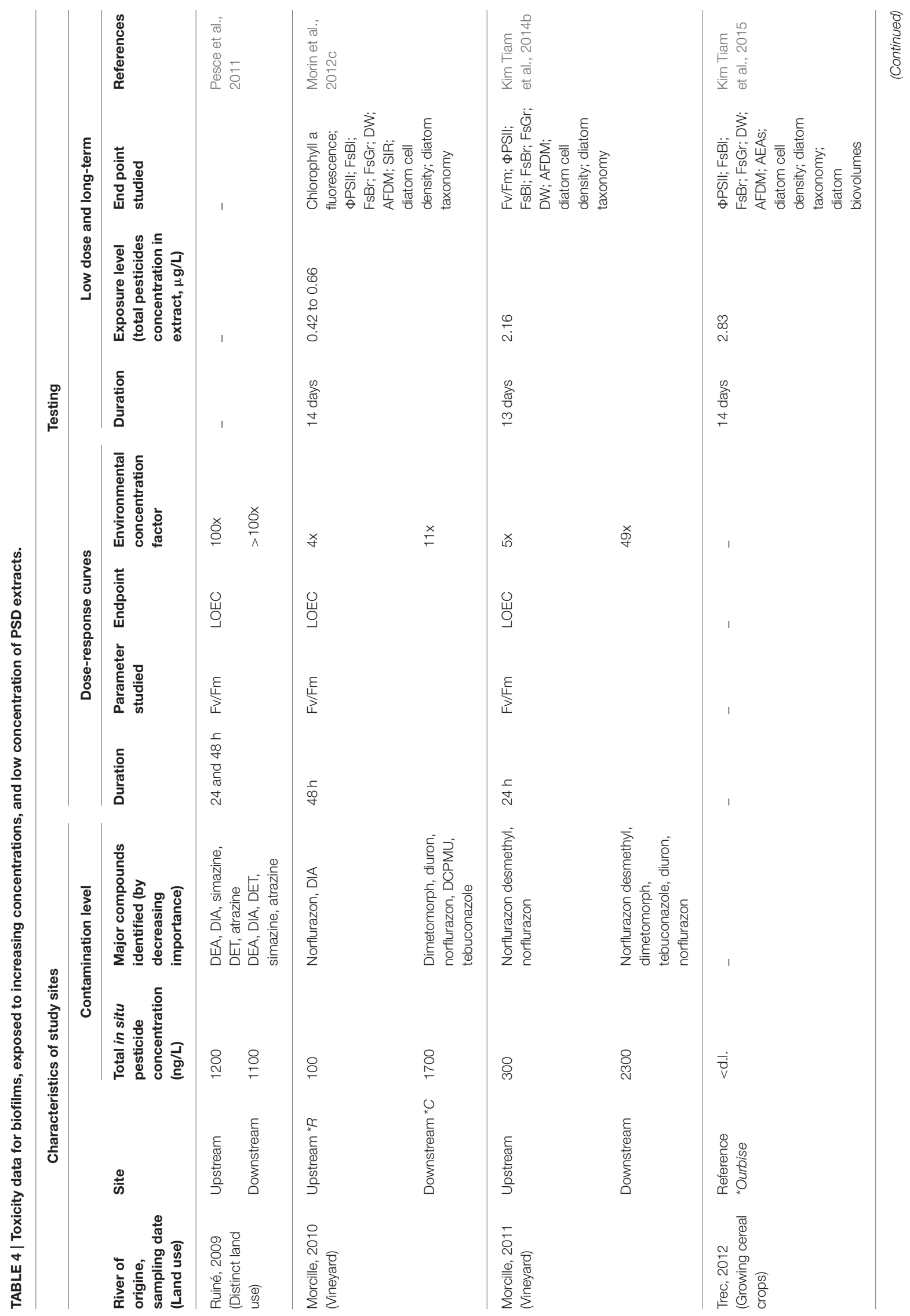




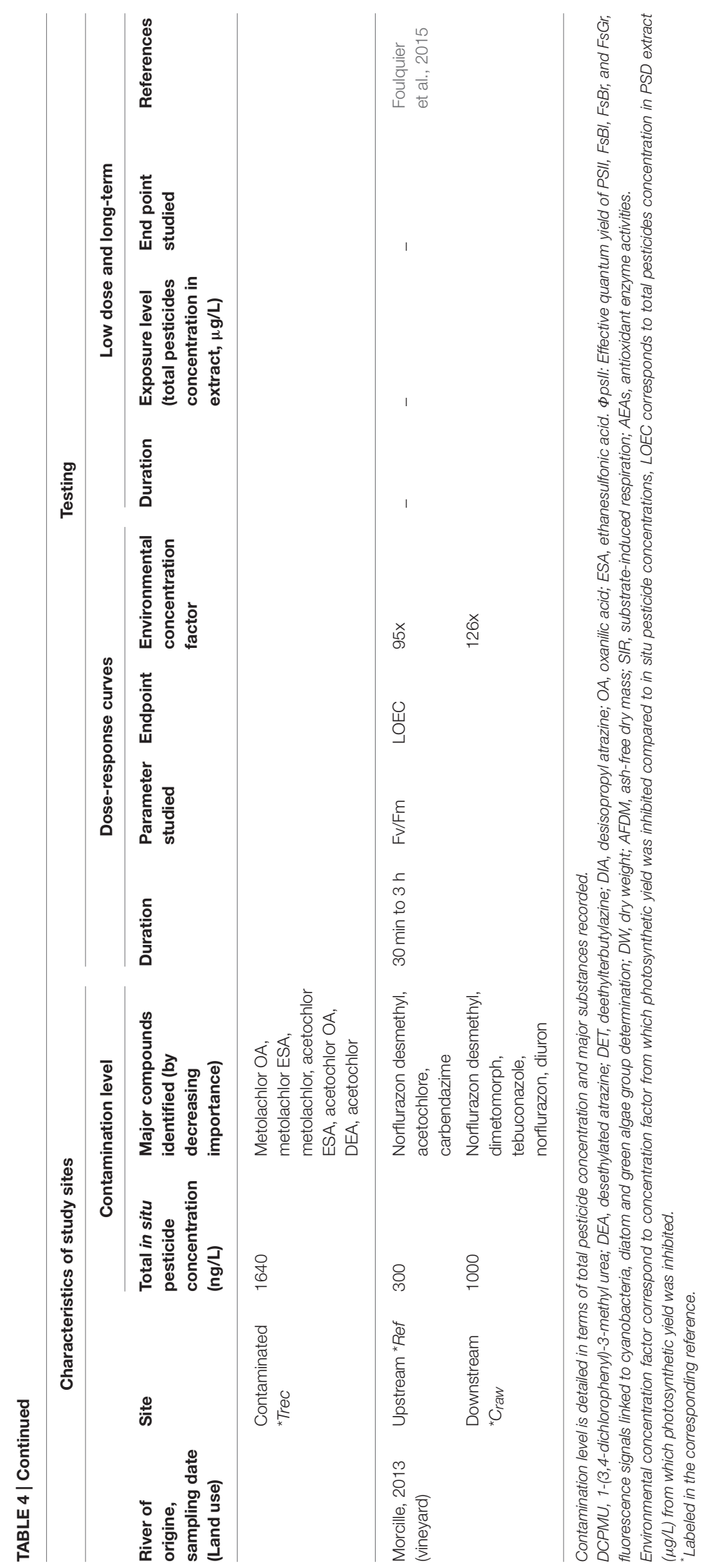


to low dose mixtures of contaminants during 2-week periods. In Kim Tiam et al. (2014b, 2015), changes in biofilm biomass, growth, taxonomic structure and function (algal fluorescence and detoxification related endpoints) observed over 2 weeks confirmed the potential of the use of $\mathrm{PE}$ in long-term exposures to assess the impacts of low dose mixtures, as found in the field. These impacts differed depending on biofilm history (previously exposed or not, and thus species composition and adaptation Kim Tiam et al., 2014b). These works highlighted that long-term exposure to low dose mixtures impacts aquatic organisms at a relatively short time scale. They showed the relevance of POCIS extracts in such laboratory approaches.

\section{IV.Questioning and Future Challenges}

The uncertainties related to the use of PSD extracts for toxicity testing on microalgae cover issues related to both, passive sampling techniques (Table 2) and assessment techniques in microalgae laboratory experiments.

\section{How to Consider Variation in Sampling Rates of the Compounds Trapped by PSD?}

Most of the uncertainties related to the use of PSD extracts for toxicity testing are preoccupations shared with environmental chemists (Harman et al., 2012; Morin et al., 2012a). They notably question the representativeness of the sampled fractions in relation to in situ exposure. In the case of POCIS, a wide range of compounds is accumulated and a posteriori calculation of timeweighted average concentrations is possible for substances whose sampling rates have been calibrated (Table 1). Therefore, when the sampling rates are well-defined, environmental concentration can be either expressed as equivalent of the $\mathrm{EC}_{50}$ (Kim Tiam et al., 2014 b) estimated from dose-response curves or simulated, under controlled laboratory conditions, with appropriate dilution levels of the PSD extracts (Kim Tiam et al., 2015). However, with the aim of testing the mixture toxicity by using POCIS extracts, the composition of the extract may be quite different from in situ concentrations. This issue is mainly due to the variability of the sampling rates (e.g., POCIS sampling rates typically ranging from 80 to $300 \mathrm{~mL} /$ day, depending on the compound properties and flow velocity; Harman et al., 2012). To overcome this limitation, several approach can be used such as in situ calibration (Mazzella et al., 2010; Ibrahim et al., 2013), use of passive flow monitor (PFM; O’Brien et al., 2011) or appropriate PRC (Mazzella et al., 2010; Dalton et al., 2014; Lissalde et al., 2014), or just checking sufficient flow velocity (e.g., $\geq 2 \mathrm{~cm} / \mathrm{s}$ ) on the field (Di Carro et al., 2014).

\section{Are PSDs Able to Cover the Entire Range of Contaminants Present in the Water Phase?}

PSD extracts do not reveal the entire complexity of the studied system, since each sampler have a defined selectivity in terms of polarity for organic compounds, or charge for inorganic species (Table 1). One passive sampler could only integrate substances with similar characteristics, and could thus avoid interactions between species having opposite physico-chemical properties. In the case where rivers are subjected to contaminations by chemical families having very different physico-chemical characteristics, using only one PSD to calculate water chemical concentrations can lead to underestimation (in term of number of chemicals) of the contamination. In this case, the use of different PSDs can be needed in order to better represent the mixture of chemicals the aquatic organisms are exposed to. Extracts of these different PSD could thus be used together (weighted by their average sampling rates) to perform toxicity assessment in order to better evaluate mixture effects. This is particularly relevant in sites impacted by vineyard treatments where organic pesticides (i.e., diuron, norflurazon, dimetomorph, tebuconazole, norflurazon desmethyl...) and inorganic pesticides (i.e., copper and arsenic) are used together (Morin et al., 2012c). This could permit to better take in account additivity, synergism, or antagonism effects in environmental risk assessment of mixtures. For example, several studies demonstrated that the co-occurrence of copper and glyphosate reduces their respective toxicity (Tsui et al., 2005; Zhou et al., 2013).

\section{How are Peaks of Contamination Integrated by PSD?}

Studying the risk linked to time-varying exposure using mixtures require $\mathrm{PSD}$ to adequately sample pulses, especially in the case of substances with a rapid onset of action. A lagtime in accumulation of some compounds was described in POCIS, due to mass transfert through the water boundary layer and the membrane of the device (Belles et al., 2014; Lissalde et al., 2014). Regarding polar PSD like POCIS and Chemcatcher ${ }^{\circledR}$, some study showed their applicability for integrating peaks of contamination (at least 10 times the background concentration) for 24-96 h periods, and for moderately polar pesticides $\left(\log \mathrm{K}_{\mathrm{ow}}=1.79\right.$ 3.21; Mazzella et al., 2008; Shaw and Mueller, 2009). However, integration of very short event (i.e., few hours only) and for a large range of pesticides must be addressed, since depending on the lagtime of the chemical of interest, POCIS could be unsuitable to capture short peak events, which could notably affect aquatic life.

\section{Is the Fraction Sampled by PSD Representative of the Compounds Available for Aquatic Organisms?}

Harman et al. (2012) put forward that passive samplers mimic the uptake of xenobiotics by organisms, thus making the use of PSD extracts more relevant ecotoxicologically. Dissolved waterborne compounds, i.e., the fraction sampled by polar PSDs, are generally expected to be the most bioavailable to organisms and thus responsible of the toxicity. However, there are processes other than passive diffusion that are expected to occur in organisms: active uptake, metabolization, etc. Moreover, in the case of biofilms, contaminated particles can be entrapped by the EPS matrix, resulting in close contact between particulate toxicants and organisms. This was demonstrated for metals, the particulate fraction being the most correlated with bioaccumulation (Morin et al., 2008a). There is, thus, an urgent need to determine the toxicokinetics of pesticides in biofilms, and whether bioaccumulated quantities are, or not, a better estimate to assess toxicity (Sappington et al., 2011). In this complex matrix where internal physicochemistry differs from water characteristics, the toxicant may be released and made available to the organisms. 
The particulate exposure pathway can thus not be ruled out, especially in the case of hydrophobic pesticides (Coat et al., 2011). On the contrary Poulier et al. (2014) showed that polar pesticides are in majority found in the dissolve fraction.

\section{Can We Identify the Compound(s) Responsible for Toxicity in Mixtures?}

The global toxicity of pesticide mixtures can thus be assessed in a non a priori approach based on the use of a "blackbox" contaminant. Kim Tiam et al. (2015) demonstrated that longterm and low dose exposure to POCIS extracts and to a reconstituted mixture of the 12 major pesticides drove similar functional and structural changes in biofilm. In that study, the adverse effects of PSD extracts were thus due to a limited number of toxic compounds.

Petrovic et al. (2011) showed a very limited number of toxic compounds often explain the adverse effects of complex environmental mixtures. In such cases, the identification of the compound(s) responsible for toxicity can be expected from EDA (Effect-Directed Analysis, Brack, 2003), which combines chemical and biological analytical approaches. Booij et al. (2014) used this approach in order to identified the main chemical stressors that negatively affect photosynthetic efficiency in marine microalgae of the Dutch estuarine and coastal waters. However, important drawbacks of these approaches rely on the fact they are laborious and time consuming, especially when diverse bioassays (endpoints) are required to appropriately assess potential toxicity. Moreover technical bias can not allow to identify the compound(s) responsible for toxicity in case of lose of toxicity of the entire extract reconstituted from the fractions. From an analytical point of view, the development of non-targeted techniques such as the use of time-of-flight high resolution mass spectrometry could help identifying the major contaminants of the PSDs "blackbox" (Hug et al., 2014; Guibal et al., 2015).

\section{How to Take into Consideration Intra and Inter-Species Sensitivity Variations in Single Species Testing?}

Enormous databases (e.g., ECOTOXicology knowledgebase, Pesticide Properties DataBase, etc.) containing toxicity testing data have been built over decades. Dose-response testing based on a variety of algal species represents the large majority of toxicity testing. The $\mathrm{EC}_{50}$, NOEC, and LOEC are the most widely used parameters for toxicity characterization and comparison. Different species (Leboulanger et al., 2001; Larras et al., 2012) or clones (Ivorra et al., 2002; Roubeix et al., 2012) can have significant differences regarding to their sensitivity to toxicant. Because of that comparing and interpreting $\mathrm{EC}_{50}$, NOEC, and LOEC from different studies can be challenging. One way to easily compare toxicity data could be the wide use of toxicity reference compound and toxic units approach as it is commonly applied when assessing PSD extract toxicity in particular in Effect-Directed Analysis studies (Shaw et al., 2009; Vermeirssen et al., 2009).

\section{Do We Need More Consistency between Toxicity Studies on Microalgae?}

In normalized toxicity tests using microalgae, experimental conditions regarding media and reagents, equipment, procedure, validity criteria, and calculations are set in order to standardize the assay (NF EN ISO 8692 10253, 2006; 2012). Non-normalized toxicity testing is also widely used in order to better taking in account species diversity and environmental conditions. In these studies, algal concentration, exposure medium, or exposure duration vary and often make comparison difficult between studies as shown by Eklund and Kautsky (2003) in a review on toxicity testing with marine macroalgae. In this study, the authors pointed out the need for method standardization. This underlines the need for a document stipulating the minimum information for publication of dose-response experiments.

This need for more consistency between toxicity studies has been recently pointed out in the case of studies applying the PICT concept (Lambert et al., 2015; Tlili et al., 2015). Tlili et al. (2015) propose practical guidance and identified a list of research issues that should be considered in order to make the PICT approach an ecologically relevant risk assessment tool of chemicals in aquatic systems. One major issues concerned standardization of PICT measurements regarding control of microbial colonization, use of a standardized medium for tolerance measurements, and normalization of tolerance values.

\section{Can We Deal with Fluctuating Concentrations and Time-Dependent Effects in Bioassays?}

Intermittent discharges of pesticides in agricultural watersheds are generally linked to rain events occurring after crop application (e.g., Rabiet et al., 2010). They result, for aquatic organisms, in fluctuating exposure alternating peaks and lower concentrations. In laboratory experiments, nominal concentrations are generally defined for each exposure condition. These concentrations are wanted to be maintained constant through the entire test duration. In reality, toxicant concentrations often differ from the nominal ones due to adsorption to the experimental units, volatilization, or degradation. Nevertheless, these variations of concentration can be minimizing by using flow-through test compared to static-renewal test or static toxicity test. Almost all toxicity testing are based on constant concentrations of exposure what is poorly representative of aquatic organisms' exposure in the environment and result in several shortcomings. The impacts of pulse insecticide exposure scenarios on fish and invertebrates have been widely studied (see review in Chèvre and Vallotton, 2013). In contrast, the responses of algae to intermittent herbicide contamination have mainly been assessed through laboratory bioassays with the model microalgae Scenedesmus vacuolatus (Vallotton et al., 2008a,b, 2009). Copin et al. (2015) modeled the effects of sequential exposures to isoproturon on the growth of Scenedesmus vacuolatus, taking into account pulse duration and concentration. Highest inhibition was caused either by short-term high dose or by long-term low dose scenarios. Fluctuating exposure was also shown to impact biofilms, depending on the number of pulses (Tlili et al., 2008, 
2011c) and on peak duration (Gustavson et al., 2003; Laviale et al., 2011).

\section{CONCLUSIONS}

Classical approaches in mixture toxicity consist in using models incremented with data obtained from single compound toxicity tests, these approaches permit to apprehend the relations of additivity, antagonism or synergism occurring in the mixture but are restricted to mixtures containing a very limited number of substances which are poorly representative of environmental contamination. The capacity of PSDs to accumulate diverse contaminants permits to better estimate the environmental contamination. Their accumulation properties also made PSDs excellent tools for mixture toxicity assessment by the direct use of their extracts in ecotoxicological testing. The main advantages of such approach is that mixture effects are integrated, metabolites are taking in account, and it is a without a priori approach (PSD extracts are used as "blackbox" composite contaminant).

In this paper we presented studies where polar PSDs and toxicity assays at different biological scales have been successfully used for pesticide mixture toxicity assessment. The coupled use of POCIS or Chemcatcher ${ }^{\circledR}$ extracts and toxicity testing on microalgae single species has demonstrated its relevance for predicting phytotoxicity of mixtures as shown by the general agreement between the toxicity measured in the bioassay and predicted based on chemical analytical results. In order to increase ecological relevance biofilms have been used as biological model to evaluate POCIS extracts toxicity.

\section{REFERENCES}

Aguilar-Martínez, R., Gómez-Gómez, M. M., and Palacios-Corvillo, M. A. (2011). Mercury and organotin compounds monitoring in fresh and marine waters across Europe by Chemcatcher passive sampler. Int. J. Environ. Anal. Chem. 91, 1100-1116. doi: 10.1080/03067310903199534

Allan, I. J., Vrana, B., Greenwood, R., Mills, G. A., Knutsson, J., Holmberg, A., et al. (2006). Strategic monitoring for the European Water Framework Directive. TrAC Trends Anal. Chem. 25, 704-715. doi: 10.1016/j.trac.2006.05.009

Alvarez, D. A. (1999). Development of an Integrative Sampling Device for Hydrophilic Organic Contaminants in Aquatic Environments. Ph.D., thesis, University of Missouri-Columbia, Columbia, MO.

Alvarez, D. A., Petty, J. D., Huckins, J. N., Jones-Lepp, T. L., Getting, D. T., Goddard, J. P., et al. (2004). Development of a passive, in situ, integrative sampler for hydrophilic organic contaminants in aquatic environments. Environ. Toxicol. Chem. 23, 1640-1648. doi: 10.1897/03-603

Artigas, J., Arts, G., Babut, M., Caracciolo, A. B., Charles, S., Chaumot, A., et al. (2012). Towards a renewed research agenda in ecotoxicology. Environ. Poll. 160, 201-206. doi: 10.1016/j.envpol.2011.08.011

Balaam, J. L., Grover, D., Johnson, A. C., Jürgens, M., Readman, J., Smith, A. J., et al. (2010). The use of modelling to predict levels of estrogens in a river catchment: how does modelled data compare with chemical analysis and in vitro yeast assay results? Sci. Total Environ. 408, 4826-4832. doi: 10.1016/j.scitotenv.2010.07.019

Bargar, T. A., Garrison, V. H., Alvarez, D. A., and Echols, K. R. (2013). Contaminants assessment in the coral reefs of Virgin Islands National Park and Virgin Islands Coral Reef National Monument. Mar. Pollut. Bull. 70, 281-288. doi: 10.1016/j.marpolbul.2013.03.001

Barral-Fraga, L., Morin, S., Rovira, M. D. M., Urrea, G., Magellan, K., and Guasch, H. (2016). Short-term arsenic exposure reduces diatom cell size in biofilm communities. Environ.
This approach has been successfully used for rivers subjected to agricultural or distinct landuse pressure resulting in a contamination dominated by herbicides. It permitted to evidence acquisition of tolerance and long-term changes in community structure, demonstrating that PSD extracts can successfully be used for this purpose. Nevertheless, coupling PSDs and toxicity assays also presents some limitations that require being considered. The future studies will have to focus on questions concerning, sampling rates, sampling range, integration of peaks of contamination by PSD, bioavailability, identification of compounds responsible for toxicity, intra and inter-species sensitivity variations, consistency between toxicity studies and time-dependent effects in bioassays.

\section{AUTHOR CONTRIBUTIONS}

SK: first author, main contributor on the coupling of passive sampling and algae part. VF: second author, main contributor on the passive sampler part. SM: third author, second contributor on the coupling of passive sampling and algae part. NM: last author, second contributor on the passive sampler part.

\section{ACKNOWLEDGMENTS}

This work was supported by the PoToMAC (Potential Toxicity of pesticides in Continental Aquatic Environments: passive sampling and exposure/impact on biofilms) programme under the reference ANR-11-CESA-022 and the French National Agency for Water and Aquatic Environments (ONEMA).
Sci. Pollut. Res. 23, 4257-4270. doi: 10.1007/s11356-0154894-8

Belles, A., Pardon, P., and Budzinski, H. (2014). Development of an adapted version of polar organic chemical integrative samplers (POCIS-Nylon). Anal. Bioanal. Chem. 406, 1099-1110. doi: 10.1007/s00216-013-7286-2

Berenbaum, M. C. (1989). What is synergy? Pharmacol. Rev. 41, 93-141.

Björklund Persson, L., Morrison, G. M., Friemann, J. U., Kingston, J., Mills, G., and Greenwood, R. (2001). Diffusional behaviour of metals in a passive sampling system for monitoring aquatic pollution. J. Environ. Monitor. 3, 639-645. doi: $10.1039 / \mathrm{b} 107959 j$

Blanck, H., Wängberg, S. A., and Molander, S. (1988). "Pollution-Induced Community Tolerance - A new ecotoxicological tool," in Functional Testing of Aquatic Biota for Estimating Hazards of Chemicals, ASTM STP 988, eds J. Cairns Jr. and J. R. Pratt (Philadelphia, PA: American Society for Testing and Materials), 219-230.

Bliss, C. I. (1939). The toxicity of poisons applied jointly. Ann. Appl. Biol. 26, 585-615. doi: 10.1111/j.1744-7348.1939.tb06990.x

Bonnineau, C., Sague, I. G., Urrea, G., and Guasch, H. (2012). Light history modulates antioxidant and photosynthetic responses of biofilms to both natural (light) and chemical (herbicides) stressors. Ecotoxicology 21, 1208-1224. doi: 10.1007/s10646-012-0876-5

Booij, P., Vethaak, A. D., Leonards, P. E. G., Sjollema, S. B., Kool, J., de Voogt, P., et al. (2014). Identification of photosynthesis inhibitors of pelagic marine algae using 96-well plate microfractionation for enhanced throughput in effectdirected analysis. Environ. Sci. Technol. 48, 8003-8011. doi: 10.1021/es405428t

Brack, W. (2003). Effect-directed analysis: a promising tool for the identification of organic toxicants in complex mixtures? Anal. Bioanal. Chem. 377, 397-407. doi: 10.1007/s00216-003-2139-z

Bruce, R. D. (1985). An up-and-down procedure for acute toxicity testing. Fundam. Appl. Toxicol. 5, 151-157. doi: 10.1016/0272-0590(85)90059-4 
Bruce, R. D. (1987). A confirmatory study of the up-and-down method for acute oral toxicity testing. Fundam. Appl. Toxicol. 8, 97-100. doi: 10.1016/02720590(87)90104-7

Camilleri, J., Morin, N., Miège, C., Coquery, M., and Cren-Olivé, C. (2012). Determination of the uptake and release rates of multifamilies of endocrine disruptor compounds on the polar C18 Chemcatcher. Three potential performance reference compounds to monitor polar pollutants in surface water by integrative sampling. J. Chromatogr. A 1237, 37-45. doi: 10.1016/j.chroma.2012.03.025

Cedergreen, N., Abbaspoor, M., Sørensen, H., and Streibig, J. C. (2007a). Is mixture toxicity measured on a biomarker indicative of what happens on a population level? A study with Lemna minor. Ecotoxicol. Environ. Saf. 67, 323-332. doi: 10.1016/j.ecoenv.2006.12.006

Cedergreen, N., Kudsk, P., Mathiassen, S. K., and Streibig, J. C. (2007b). Combination effects of herbicides on plants and algae: do species and test systems matter? Pest Manag. Sci. 63, 282-295. doi: 10.1002/ps.1353

Charriau, A., Lissalde, S., Poulier, G., Mazzella, N., Buzier, R., and Guibaud, G. (2016). Overview of the Chemcatcher ${ }^{\circledR}$ for the passive sampling of various pollutants in aquatic environments Part A: principles, calibration, preparation and analysis of the sampler. Talanta 148, 556-571. doi: 10.1016/j.talanta.2015.06.064

Chen, C.-E., Zhang, H., Ying, G.-G., and Jones, K. C. (2013). Evidence and recommendations to support the use of a novel passive water sampler to quantify antibiotics in wastewaters. Environ. Sci. Technol. 47, 13587-13593. doi: $10.1021 /$ es402662g

Chèvre, N., and Gregorio, V. (2013). "Mixture effects in ecotoxicology," in Encyclopedia of Aquatic Ecotoxicology, eds J.-F. Férard and C. Blaise (Dordrecht: Springer Science), 729-736.

Chèvre, N., Loepfe, C., Singer, H., Stamm, C., Fenner, K., and Escher, B. I. (2006). Including mixtures in the determination of water quality criteria for herbicides in surface water. Environ. Sci. Technol. 40, 426-435. doi: 10.1021/es050239l

Chèvre, N., and Vallotton, N. (2013). "Pulse exposure in ecotoxicology," in Encyclopedia of Aquatic Ecotoxicology, eds J.-F. Férard and C. Blaise (Dordrecht: Springer Science), 917-925.

Coat, S., Monti, D., Legendre, P., Bouchon, C., Massat, F., and Lepoint, G. (2011). Organochlorine pollution in tropical rivers (Guadeloupe): role of ecological factors in food web bioaccumulation. Environ. Pollut. 159, 1692-1701. doi: 10.1016/j.envpol.2011.02.036

Copin, P.-J., Coutu, S., and Chèvre, N. (2015). Modelling the effect of fluctuating herbicide concentrations on algae growth. Ecotoxicol. Environ. Saf. 113, 214-222. doi: 10.1016/j.ecoenv.2014.12.010

Corcoll, N., Bonet, B., Leira, M., and Guasch, H. (2011). Chl-a fluorescence parameters as biomarkers of metal toxicity in fluvial biofilms: an experimental study. Hydrobiologia 673, 119-136. doi: 10.1007/s10750-011-0763-8

Creusot, N., Kinani, S., Balaguer, P., Tapie, N., LeMenach, K., Maillot-Maréchal, E., et al. (2010). Evaluation of an hPXR reporter gene assay for the detection of aquatic emerging pollutants: screening of chemicals and application to water samples. Anal. Bioanal. Chem. 396, 569-583. doi: 10.1007/s00216-009-3310-y

Dalton, R. L., Pick, F. R., Boutin, C., and Saleem, A. (2014). Atrazine contamination at the watershed scale and environmental factors affecting sampling rates of the polar organic chemical integrative sampler (POCIS). Environ. Pollut. 189, 134-142. doi: 10.1016/j.envpol.2014.02.028

Davison, W., and Zhang, H. (1994). In situ speciation measurements of trace components in natural waters using thin-film gels. Nature $367,546-548$. doi: $10.1038 / 367546 \mathrm{a} 0$

Debenest, T., Pinelli, E., Coste, M., Silvestre, J., Mazzella, N., Madigou, C., et al. (2009). Sensitivity of freshwater periphytic diatoms to agricultural herbicides. Aquat. Toxicol. 93, 11-17. doi: 10.1016/j.aquatox.2009.02.014

de Zwart, D., and Posthuma, L. (2005). Complex mixture toxicity for single and multiple species: proposed methodologies. Environ. Toxicol. Chem. 24, 2665-2676. doi: 10.1897/04-639R.1

Di Carro, M., Bono, L., and Magi, E. (2014). A simple recirculating flow system for the calibration of polar organic chemical integrative samplers (POCIS): effect of flow rate on different water pollutants. Talanta 120, 30-33. doi: 10.1016/j.talanta.2013.11.088

Echeveste, P., Tovar-Sánchez, A., and Agustí, S. (2014). Tolerance of polar phytoplankton communities to metals. Environ. Pollut. 185, 188-195. doi: 10.1016/j.envpol.2013.10.029
Eklund, B. T., and Kautsky, L. (2003). Review on toxicity testing with marine macroalgae and the need for method standardization-exemplified with copper and phenol. Mar. Pollut. Bull. 46, 171-181. doi: 10.1016/S0025-326X(02) 00225-4

Escher, B. I., Bramaz, N., Eggen, R. I. L., and Richter, M. (2005). In vitro assessment of modes of toxic action of pharmaceuticals in aquatic life. Environ. Sci. Technol. 39, 3090-3100. doi: 10.1021/es048590e

Escher, B. I., Quayle, P., Muller, R., Schreiber, U., and Mueller, J. F. (2006). Passive sampling of herbicides combined with effect analysis in algae using a novel high-throughput phytotoxicity assay (Maxi-Imaging-PAM). J. Environ. Monitor. 8, 456-464. doi: 10.1039/b517512g

Fauvelle, V., Mazzella, N., Belles, A., Moreira, A., Allan, I., and Budzinski, H. (2014). Optimization of the polar organic chemical integrative sampler for the sampling of acidic and polar herbicides. Anal. Bioanal. Chem. 406, 3191-3199. doi: 10.1007/s00216-014-7757-0

Fauvelle, V., Mazzella, N., Delmas, F., Madarassou, K., Eon, M., and Budzinski, H. (2012). Use of mixed-mode ion exchange sorbent for the passive sampling of organic acids by Polar Organic Chemical Integrative Sampler (POCIS). Environ. Sci. Technol. 46, 13344-13353. doi: 10.1021/es3 035279

Fauvelle, V., Nhu-Trang, T.-T., Feret, T., Madarassou, K., Randon, J., and Mazzella, N. (2015). Evaluation of titanium dioxide as a binding phase for the passive sampling of glyphosate and aminomethyl phosphonic acid in an aquatic environment. Anal. Chem. 87, 6004-6009. doi: 10.1021/acs.analchem.5b 00194

Fernández, D., Vermeirssen, E. L. M., Bandow, N., Muñoz, K., and Schäfer, R. B. (2014). Calibration and field application of passive sampling for episodic exposure to polar organic pesticides in streams. Environ. Pollut. 194, 196-202.

Fernández-Alba, A. R., Hernando, M. D., Piedra, L., and Chisti, Y. (2002). Toxicity evaluation of single and mixed antifouling biocides measured with acute toxicity bioassays. Anal. Chim. Acta 456, 303-312. doi: 10.1016/S00032670(02)00037-5

Fisher, N. S., Carpenter, E. J., Remsen, C. C., and Wurster, C. F. (1974). Effects of PCB on interspecific competition in natural and gnotobiotic phytoplankton communities in continuous and batch cultures. Microb. Ecol. 1, 39-50. doi: 10.1007/BF02512378

Foulquier, A., Morin, S., Dabrin, A., Margoum, C., Mazzella, N., and Pesce, S. (2015). Effects of mixtures of dissolved and particulate contaminants on phototrophic biofilms: new insights from a PICT approach combining toxicity tests with passive samplers and model substances. Environ. Sci. Pollut. Res. 22, 4025-4036. doi: 10.1007/s11356-014-3289-6

Gatidou, G., and Thomaidis, N. S. (2007). Evaluation of single and joint toxic effects of two antifouling biocides, their main metabolites and copper using phytoplankton bioassays. Aquat. Toxicol. 85, 184-191. doi: 10.1016/j.aquatox.2007.09.002

Gold, C., Feurtet-Mazel, A., Coste, M., and Boudou, A. (2003). Effects of cadmium stress on periphytic diatom communities in indoor artificial streams. Freshw. Biol. 48, 316-328. doi: 10.1046/j.1365-2427.2003.00980.x

Guasch, H., Artigas, J., Bonet, B., Bonnineau, C., Canals, O., Corcoll, N., et al. (2016). "The use of biofilms to assess the effects of chemicals on freshwater ecosystems," in Aquatic Biofilms: Ecology, Water Quality and Wastewater Treatment, eds A. M. Romaní, H. Guasch, and M. D. Balaguer (Poole, UK: Horizon Scientific Press; Caister Academic Press), 1-200.

Guasch, H., Bonet, B., Bonnineau, C., Corcoll, N., López-Doval, J., Muñoz, I., et al. (2012). "How to link field observations with causality? Field and experimental approaches linking chemical pollution with ecological alterations," in Emerging and Priority Pollutants in Rivers, eds H. Guasch, A. Ginebreda, and A. Geiszinger (Berlin; Heidelberg: Springer), 181-218.

Guibal, R., Lissalde, S., Charriau, A., Poulier, G., Mazzella, N., and Guibaud, G. (2015). Coupling passive sampling and time of flight mass spectrometry for a better estimation of polar pesticide freshwater contamination: simultaneous target quantification and screening analysis. J. Chromatogr. A 1387, 75-85. doi: 10.1016/j.chroma.2015.02.014

Gunold, R., Schäfer, R. B., Paschke, A., Schüürmann, G., and Liess, M. (2008). Calibration of the Chemcatcher ${ }^{\circledR}$ passive sampler for monitoring selected polar and semi-polar pesticides in surface water. Environ. Pollut. 155, 52-60. doi: 10.1016/j.envpol.2007.10.037 
Gustavson, K., Møhlenberg, F., and Schlüter, L. (2003). Effects of exposure duration of herbicides on natural stream periphyton communities and recovery. Arch. Environ. Contam. Toxicol. 45, 48-58. doi: 10.1007/s00244-002-0079-9

Gustavson, K., and Wängberg, S. Å. (1995). Tolerance induction and succession in microalgae communities exposed to copper and atrazine. Aquat. Toxicol. 32, 283-302. doi: 10.1016/0166-445X(95)00002-L

Harman, C., Allan, I. J., and Vermeirssen, E. L. M. (2012). Calibration and use of the polar organic chemical integrative sampler-a critical review. Environ. Toxicol. Chem. 31, 2724-2738. doi: 10.1002/etc.2011

Hickie, B. E., Hutchinson, N. J., Dixon, D. G., and Hodson, P. V. (1993). Toxicity of trace metal mixtures to alevin rainbow trout (Oncorhynchus mykiss) and larval fathead minnow (Pimephales promelas) in Soft, Acidic Water. Can. J. Fisher. Aquat. Sci. 50, 1348-1355. doi: 10.1139/f93-154

Huckins, J. N., Tubergen, M. W., and Manuweera, G. K. (1990). Semipermeable membrane devices containing model lipid: a new approach to monitoring the bioavaiiability of lipophilic contaminants and estimating their bioconcentration potential. Chemosphere 20, 533-552. doi: 10.1016/0045-6535(90)90110-F

Hug, C., Ulrich, N., Schulze, T., Brack, W., and Krauss, M. (2014). Identification of novel micropollutants in wastewater by a combination of suspect and nontarget screening. Environ. Pollut. 184, 25-32. doi: 10.1016/j.envpol.2013.07.048

Ibrahim, I., Togola, A., and Gonzalez, C. (2013). In-situ calibration of POCIS for the sampling of polar pesticides and metabolites in surface water. Talanta 116, 495-500. doi: 10.1016/j.talanta.2013.07.028

Ivorra, N., Barranguet, C., Jonker, M., Kraak, M. H., and Admiraal, W. (2002). Metal-induced tolerance in the freshwater microbenthic diatom Gomphonema parvulum. Environ. Pollut. 116, 147-157. doi: 10.1016/S0269-7491(01)00152-X

Jálová, V., Jarošová, B., Bláha, L., Giesy, J. P., Ocelka, T., Grabic, R., et al. (2013). Estrogen-, androgen- and aryl hydrocarbon receptor mediated activities in passive and composite samples from municipal waste and surface waters. Environ. Int. 59, 372-383. doi: 10.1016/j.envint.2013.06.024

Jarosova, B., Blaha, L., Vrana, B., Randak, T., Grabic, R., Giesy, J. P., et al. (2012). Changes in concentrations of hydrophilic organic contaminants and of endocrine-disrupting potential downstream of small communities located adjacent to headwaters. Environ. Int. 45, 22-31. doi: 10.1016/j.envint.2012.04.001

Kaserzon, S. L., Hawker, D. W., Booij, K., O’Brien, D. S., Kennedy, K., Vermeirssen, E. L. M., et al. (2014a). Passive sampling of perfluorinated chemicals in water: in-situ calibration. Environ. Pollut. 186, 98-103. doi: 10.1016/j.envpol.2013.11.030

Kaserzon, S. L., Hawker, D. W., Kennedy, K., Bartkow, M., Carter, S., Booij, K., et al. (2014b). Characterisation and comparison of the uptake of ionizable and polar pesticides, pharmaceuticals and personal care products by POCIS and Chemcatchers. Environ. Sci. Process. Impacts 16, 2517-2526. doi: $10.1039 / \mathrm{c} 4 \mathrm{em} 00392 \mathrm{f}$

Kim Tiam, S., Libert, X., Morin, S., Gonzalez, P., Feurtet-Mazel, A., and Mazzella, N. (2014a). Single and mixture effects of pesticides and a degradation product on fluvial biofilms. Environ. Monit. Assess. 186, 3931-3939. doi: 10.1007/s10661-014-3669-x

Kim Tiam, S., Morin, S., Bonet, B., Guasch, H., Feurtet-Mazel, A., Eon, M., et al. (2015). Is the toxicity of pesticide mixtures on river biofilms accounted for solely by the major compounds identified? Environ. Sci. Pollut. Res. 22, 4009-4024. doi: 10.1007/s11356-014-3373-y

Kim Tiam, S., Morin, S., Pesce, S., Feurtet-Mazel, A., Moreira, A., Gonzalez, P., et al. (2014b). Environmental effects of realistic pesticide mixtures on natural biofilm communities with different exposure histories. Sci. Total Environ. 473-474:496-506. doi: 10.1016/j.scitotenv.2013.12.060

Kingston, J. K., Greenwood, R., Mills, G. A., Morrison, G. M., and Bjorklund Persson, L. (2000). Development of a novel passive sampling system for the time-averaged measurement of a range of organic pollutants in aquatic environments. J. Environ. Monitor. 2, 487-495. doi: 10.1039/b003532g

Lambert, A. S., Pesce, S., Foulquier, A., Gahou, J., Coquery, M., and Dabrin, A. (2015). Improved short-term toxicity test protocol to assess metal tolerance in phototrophic periphyton: toward standardization of PICT approaches. Environ. Sci. Pollut. Res. 22, 4037-4045. doi: 10.1007/s11356-014-3505-4

Larras, F., Bouchez, A., Rimet, F., and Montuelle, B. (2012). Using bioassays and Species Sensitivity Distributions to assess herbicide toxicity towards benthic diatoms. PLoS ONE 7:e44458. doi: 10.1371/journal.pone.0044458
Larras, F., Montuelle, B., and Bouchez, A. (2013). Assessment of toxicity thresholds in aquatic environments: does benthic growth of diatoms affect their exposure and sensitivity to herbicides? Sci. Total Environ. 463-464:469-477. doi: 10.1016/j.scitotenv.2013.06.063

Larras, F., Rimet, F., Gregorio, V., Bérard, A., Leboulanger, C., Montuelle, B., et al. (2016). Pollution-induced community tolerance (PICT) as a tool for monitoring Lake Geneva long-term in situ ecotoxic restoration from herbicide contamination. Environ. Sci. Pollut. Res. 23, 4301-4311. doi: 10.1007/s11356015-5302-0

Laviale, M., Morin, S., and Créach, A. (2011). Short term recovery of periphyton photosynthesis after pulse exposition to the photosystem II inhibitors atrazine and isoproturon. Chemosphere 84, 731-734. doi: 10.1016/j.chemosphere.2011.03.035

Leboulanger, C., Rimet, F., Heme de Lacotte, M., and Bérard, A. (2001). Effects of atrazine and nicosulfuron on freshwater microalgae. Environ. Int. 26, 131-135. doi: 10.1016/S0160-4120(00)00100-8

Li, H., Helm, P. A., Paterson, G., and Metcalfe, C. D. (2011). The effects of dissolved organic matter and $\mathrm{pH}$ on sampling rates for polar organic chemical integrative samplers (POCIS). Chemosphere 83, 271-280. doi: 10.1016/j.chemosphere.2010.12.071

Liscio, C., Magi, E., Di Carro, M., Suter, M. J. F., and Vermeirssen, E. L. M. (2009). Combining passive samplers and biomonitors to evaluate endocrine disrupting compounds in a wastewater treatment plant by LC/MS/MS and bioassay analyses. Environ. Pollut. 157, 2716-2721. doi: 10.1016/j.envpol.2009.04.034

Lissalde, S., Charriau, A., Poulier, G., Mazzella, N., Buzier, R., and Guibaud, G. (2016). Overview of the Chemcatcher ${ }^{\circledR}$ for the passive sampling of various pollutants in aquatic environments Part B: field handling and environmental applications for the monitoring of pollutants and their biological effects. Talanta 148, 572-582. doi: 10.1016/j.talanta.2015.06.076

Lissalde, S., Mazzella, N., Fauvelle, V., Delmas, F., Mazellier, P., and Legube, B. (2011). Liquid chromatography coupled with tandem mass spectrometry method for thirty-three pesticides in natural water and comparison of performance between classical solid phase extraction and passive sampling approaches. J. Chromatogr. A 1218, 1492-1502. doi: 10.1016/j.chroma.2011.01.040

Lissalde, S., Mazzella, N., and Mazellier, P. (2014). Polar organic chemical integrative samplers for pesticides monitoring: Impacts of field exposure conditions. Sci. Total Environ. 488-489:188-196. doi: 10.1016/j.scitotenv.2014.04.069

Loewe, S., and Muischneck, H. (1926). Effects of combinations: mathematical basis of problem. Arch. Exp. Pathol. Pharmacol. 114, 313-326.

Magnusson, M., Heimann, K., and Negri, A. P. (2008). Comparative effects of herbicides on photosynthesis and growth of tropical estuarine microalgae. Mar. Pollut. Bull. 56, 1545-1552. doi: 10.1016/j.marpolbul.2008.05.023

Matthiessen, P., Arnold, D., Johnson, A. C., Pepper, T. J., Pottinger, T. G., and Pulman, K. G. T. (2006). Contamination of headwater streams in the United Kingdom by oestrogenic hormones from livestock farms. Sci. Total Environ. 367, 616-630. doi: 10.1016/j.scitotenv.2006.02.007

Mazzella, N., Debenest, T., and Delmas, F. (2008). Comparison between the polar organic chemical integrative sampler and the solid-phase extraction for estimating herbicide time-weighted average concentrations during a microcosm experiment. Chemosphere 73, 545-550. doi: 10.1016/j.chemosphere.2008.06.009

Mazzella, N., Dubernet, J.-F., and Delmas, F. (2007). Determination of kinetic and equilibrium regimes in the operation of polar organic chemical integrative samplers: application to the passive sampling of the polar herbicides in aquatic environments. J. Chromatogr. A 1154, 42-51. doi: 10.1016/j.chroma.2007.03.087

Mazzella, N., Lissalde, S., Moreira, S., Delmas, F., Mazellier, P., and Huckins, J. N. (2010). Evaluation of the use of performance reference compounds in an oasis-HLB adsorbent based passive sampler for improving water concentration estimates of polar herbicides in freshwater. Environ. Sci. Technol. 44, 1713-1719. doi: 10.1021/es902256m

McClellan, K., Altenburger, R., and Schmitt-Jansen, M. (2008). Pollution-induced community tolerance as a measure of species interaction in toxicity assessment. J. Appl. Ecol. 45, 1514-1522. doi: 10.1111/j.1365-2664.2008.01525.x

Montuelle, B., Dorigo, U., Berard, A., Volat, B., Bouchez, A., Tlili, A., et al. (2010). The periphyton as a multimetric bioindicator for assessing the impact of land 
use on rivers: an overview of the ArdiSres-Morcille experimental watershed (France). Hydrobiologia 657, 123-141. doi: 10.1007/s10750-010-0105-2

Morin, N., Camilleri, J., Cren-Olivé, C., Coquery, M., and Miège, C. (2013). Determination of uptake kinetics and sampling rates for 56 organic micropollutants using "pharmaceutical" POCIS. Talanta 109, 61-73. doi: 10.1016/j.talanta.2013.01.058

Morin, N., Miège, C., Coquery, M., and Randon, J. (2012a). Chemical calibration, performance, validation and applications of the polar organic chemical integrative sampler (POCIS) in aquatic environments. TrAC Trends Anal. Chem. 36, 144-175. doi: 10.1016/j.trac.2012.01.007

Morin, S., Duong, T. T., Dabrin, A., Coynel, A., Herlory, O., Baudrimont, M., et al. (2008a). Long term survey of heavy metal pollution, biofilm contamination and diatom community structure in the Riou-Mort watershed, South West France. Environ. Pollut. 151, 532-542. doi: 10.1016/j.envpol.2007.04.023

Morin, S., Duong, T. T., Herlory, O., Feurtet-Mazel, A., and Coste, M. (2008b). Cadmium toxicity and bioaccumulation in freshwater biofilms. Arch. Environ. Contam. Toxicol. 54, 173-186. doi: 10.1007/s00244-007-9022-4

Morin, S., Lambert, A.-S., Artigas, J., Coquery, M., and Pesce, S. (2012b). Diatom immigration drives biofilm recovery after chronic copper exposure. Freshw. Biol. 57, 1658-1666. doi: 10.1111/j.1365-2427.2012.02827.x

Morin, S., Pesce, S., Kim-Tiam, S., Libert, X., Coquery, M., and Mazzella, N. (2012c). Use of polar organic chemical integrative samplers to assess the effects of chronic pesticide exposure on biofilms. Ecotoxicology 21, 1570-1580. doi: 10.1007/s10646-012-0910-7

Morin, S., Proia, L., Ricart, M., Bonnineau, C., Geiszinger, A., Ricciardi, F., et al. (2010). Effects of a bactericide on the structure and survival of benthic diatom communities. Life Environ. 60, 109-116.

Moschet, C., Vermeirssen, E. L. M., Singer, H., Stamm, C., and Hollender, J. (2015). Evaluation of in-situ calibration of chemcatcher passive samplers for 322 micropollutants in agricultural and urban affected rivers. Water Res. 71, 306-317. doi: 10.1016/j.watres.2014.12.043

Müller, J. F., Manomanii, K., Mortimer, M. R., and McLachlan, M. S. (2001). Partitioning of polycyclic aromatic hydrocarbons in the polyethylene/water system. Fresenius J. Anal. Chem. 371, 816-822. doi: 10.1007/s002160101025

Muller, R., Schreiber, U., Escher, B. I., Quayle, P., Nash, S. M. B., and Mueller, J. F. (2008). Rapid exposure assessment of PSII herbicides in surface water using a novel chlorophyll a fluorescence imaging assay. Sci. Total Environ. 401, 51-59. doi: 10.1016/j.scitotenv.2008.02.062

Muller, R., Tang, J. Y. M., Thier, R., and Mueller, J. F. (2007). Combining passive sampling and toxicity testing for evaluation of mixtures of polar organic chemicals in sewage treatment plant effluent. J. Environ. Monitor. 9, 104-109. doi: 10.1039/B612430E

Newman, M. C. (2009). Fundamentals of Ecotoxicology. CRC Press.

NF EN ISO 8692 (2012). Qualité de l'eau - Essai d'inhibition de la Croissance des Algues d'eau Douce Avec des Algues Vertes Unicellulaires (in French).

NF EN ISO 10253 (2006). Qualité de l'eau - Essai d'inhibition de la Croissance des Algues Marines Avec Skeletonema costatum et Phaeodactylum tricornutum.

O'Brien, D., Bartkow, M., and Mueller, J. F. (2011). Determination of deployment specific chemical uptake rates for SDB-RPD Empore disk using a passive flow monitor (PFM). Chemosphere 83, 1290-1295. doi: 10.1016/j.chemosphere.2011.02.089

Palmes, E. D., and Gunnison, A. F. (1973). Personal monitoring device for gaseous contaminants. Am. Ind. Hyg. Assoc. J. 34, 78-81. doi: 10.1080/0002889738506810

Pandey, L. K., Han, T., and Gaur, J. P. (2015). Response of a phytoplanktonic assemblage to copper and zinc enrichment in microcosm. Ecotoxicology 24, 573-582. doi: 10.1007/s10646-014-1405-5

Parrott, J. L., and Sprague, J. B. (1993). Patterns in toxicity of sublethal mixtures of metals and organic chemicals determined by microtox ${ }^{\circledR}$ and by DNA, RNA, and protein content of fathead minnows (Pimephales promelas). Can. J. Fisheries Aquat. Sci. 50, 2245-2253. doi: 10.1139/f93-250

Paschke, A., Schwab, K., Brümmer, J., Schüürmann, G., Paschke, H., and Popp, P. (2006). Rapid semi-continuous calibration and field test of membrane-enclosed silicone collector as passive water sampler. J. Chromatogr. A 1124, 187-195. doi: 10.1016/j.chroma.2006.06.094

Pérès, F., Florin, D., Grollier, T., Feurtet-Mazel, A., Coste, M., Ribeyre, F., et al. (1996). Effects of the phenylurea herbicide isoproturon on periphytic diatom communities in freshwater indoor microcosm. Environ. Pollut. 94, 141-152. doi: 10.1016/S0269-7491(96)00080-2

Pesce, S., Fajon, C., Bardot, C., Bonnemoy, F., Portelli, C., and Bohatier, J. (2006). Effects of the phenylurea herbicide diuron on natural riverine microbial communities in an experimental study. Aquat. Toxicol. 78, 303-314. doi: 10.1016/j.aquatox.2006.03.006

Pesce, S., Lissalde, S., Lavieille, D., Margoum, C., Mazzella, N., Roubeix, V., et al. (2010). Evaluation of single and joint toxic effects of diuron and its main metabolites on natural phototrophic biofilms using a pollution-induced community tolerance (PICT) approach. Aquat. Toxicol. 99, 492-499. doi: 10.1016/j.aquatox.2010.06.006

Pesce, S., Martin-Laurent, F., Rouard, N., and Montuelle, B. (2009). Potential for microbial diuron mineralisation in a small wine-growing watershed: from treated plots to lotic receiver hydrosystem. Pest Manage. Sci. 65, 651-657. doi: $10.1002 /$ ps.1729

Pesce, S., Morin, S., Lissalde, S., Montuelle, B., and Mazzella, N. (2011). Combining polar organic chemical integrative samplers (POCIS) with toxicity testing to evaluate pesticide mixture effects on natural phototrophic biofilms. Environ. Pollut. 159, 735-741. doi: 10.1016/j.envpol.2010.11.034

Petrovic, M., Ginebreda, A., Acuña, V., Batalla, R. J., Elosegi, A., Guasch, H., et al. (2011). Combined scenarios of chemical and ecological quality under water scarcity in Mediterranean rivers. TrAC Trends Anal. Chem. 30, 1269-1278. doi: 10.1016/j.trac.2011.04.012

Petty, J. D., Huckins, J. N., Alvarez, D. A., Brumbaugh, W. G., Cranor, W. L., Gale, R. W., et al. (2004). A holistic passive integrative sampling approach for assessing the presence and potential impacts of waterborne environmental contaminants. Chemosphere 54, 695-705. doi: 10.1016/j.chemosphere.2003.08.015

Poulier, G., Lissalde, S., Charriau, A., Buzier, R., Delmas, F., Gery, K., et al. (2014). Can POCIS be used in Water Framework Directive (2000/60/EC) monitoring networks? A study focusing on pesticides in a French agricultural watershed. Sci. Total Environ. 497, 282-292. doi: 10.1016/j.scitotenv.2014.08.001

Rabiet, M., Margoum, C., Gouy, V., Carluer, N., and Coquery, M. (2010). Assessing pesticide concentrations and fluxes in the stream of a small vineyard catchment - Effect of sampling frequency. Environ. Pollut. 158, 737-748. doi: 10.1016/j.envpol.2009.10.014

Rand, G. M., and Petrocelli, S. R. (1985). Fundamentals of Aquatic Toxicology: Methods and Applications. Princeton, NJ: FMC Corp.

Reiszner, K. D., and West, P. W. (1973). Collection and determination of sulfur dioxide incorporating permeation and West-Gaeke procedure. Environ. Sci. Technol. 7, 526-532. doi: 10.1021/es60078a001

Ricart, M., Barceló, D., Geiszinger, A., Guasch, H., de Alda, M. L., Romaní, A. M., et al. (2009). Effects of low concentrations of the phenylurea herbicide diuron on biofilm algae and bacteria. Chemosphere 76, 1392-1401. doi: 10.1016/j.chemosphere.2009.06.017

Roberts, S., Vasseur, P., and Dive, D. (1990). Combined effects between atrazine, copper and $\mathrm{pH}$, on target and non target species. Water Res. 24, 485-491. doi: 10.1016/0043-1354(90)90233-V

Rotter, S., Sans-Piché, F., Streck, G., Altenburger, R., and Schmitt-Jansen, M. (2011). Active bio-monitoring of contamination in aquatic systems-An in situ translocation experiment applying the PICT concept. Aquat. Toxicol. 101, 228-236. doi: 10.1016/j.aquatox.2010.10.001

Roubeix, V., Mazzella, N., Méchin, B., Coste, M., and Delmas, F. (2011a). Impact of the herbicide metolachlor on river periphytic diatoms: experimental comparison of descriptors at different biological organization levels. Ann. Limnol. 47, 239-249. doi: 10.1051/limn/2011009

Roubeix, V., Mazzella, N., Schouler, L., Fauvelle, V., Morin, S., Coste, M., et al. (2011b). Variations of periphytic diatom sensitivity to the herbicide diuron and relation to species distribution in a contamination gradient: implications for biomonitoring. J. Environ. Monit. 13, 1768-1774. doi: 10.1039/c0em00783h

Roubeix, V., Pesce, S., Mazzella, N., Coste, M., and Delmas, F. (2012). Variations in periphytic diatom tolerance to agricultural pesticides in a contaminated river: An analysis at different diversity levels. Fresenius Environ. Bull. 21, 2090-2094.

Rusina, T. P., Smedes, F., Koblizkova, M., and Klanova, J. (2010). Calibration of silicone rubber passive samplers: experimental and modeled relations between sampling rate and compound properties. Environ. Sci. Technol. 44, 362-367. doi: $10.1021 /$ es $900938 \mathrm{r}$ 
Sabater, S., Guasch, H., Ricart, M., Romaní, A., Vidal, G., Klünder, C., et al. (2007). Monitoring the effect of chemicals on biological communities. The biofilm as an interface. Anal. Bioanal. Chem. 387, 1425-1434. doi: 10.1007/s00216-0061051-8

Sappington, K. G., Bridges, T. S., Bradbury, S. P., Erickson, R. J., Hendriks, A. J., Lanno, R. P., et al. (2011). Application of the tissue residue approach in ecological risk assessment. Integr. Environ. Assess. Manag. 7, 116-140. doi: 10.1002/ieam.116

Schmitt-Jansen, M., and Altenburger, R. (2005). Toxic effects of isoproturon on periphyton communities - a microcosm study. Estuar. Coast. Shelf Sci. 62, 539-545. doi: 10.1016/j.ecss.2004.09.016

Schmitt-Jansen, M., and Altenburger, R. (2008). Community-level microalgal toxicity assessment by multiwavelength-excitation PAM fluorometry. Aquat. Toxicol. 86, 49-58. doi: 10.1016/j.aquatox.2007.10.001

Seguin, F., Le Bihan, F., Leboulanger, C., and Bérard, A. (2002). A risk assessment of pollution: induction of atrazine tolerance in phytoplankton communities in freshwater outdoor mesocosms, using chlorophyll fluorescence as an endpoint. Water Res. 36, 3227-3236. doi: 10.1016/S0043-1354(02)00013-1

Serra, A., and Guasch, H. (2009). Effects of chronic copper exposure on fluvial systems: linking structural and physiological changes of fluvial biofilms with the in-stream copper retention. Sci. Total Environ. 407, 5274-5282. doi: 10.1016/j.scitotenv.2009.06.008

Shaw, M., and Mueller, J. F. (2009). Time integrative passive sampling: how well do Chemcatchers integrate fluctuating pollutant concentrations? Environ. Sci. Technol. 43, 1443-1448. doi: 10.1021/es8021446

Shaw, M., Negri, A., Fabricius, K., and Mueller, J. F. (2009). Predicting water toxicity: pairing passive sampling with bioassays on the Great Barrier Reef. Aquat. Toxicol. 95, 108-116. doi: 10.1016/j.aquatox.2009.08.007

Sinclair, C. J., and Boxall, A. B. A. (2003). Assessing the ecotoxicity of pesticide transformation products. Environ. Sci. Technol. 37, 4617-4625. doi: $10.1021 /$ es030038m

Tlili, A., Bérard, A., Blanck, H., Bouchez, A., Cassió, F., Eriksson, K. M., et al. (2015). Pollution-induced community tolerance (PICT): towards an ecologically relevant risk asessment of chemicals in aquatic systems. Freshw. Biol. doi: 10.1111/fwb.12558. [Epub ahead of print].

Tlili, A., Corcoll, N., Bonet, B., Morin, S., Montuelle, B., Bérard, A., et al. (2011a). In situ spatio-temporal changes in pollution-induced community tolerance to zinc in autotrophic and heterotrophic biofilm communities. Ecotoxicology 20, 1823-1839. doi: 10.1007/s10646-011-0721-2

Tlili, A., Dorigo, U., Montuelle, B., Margoum, C., Carluer, N., Gouy, V., et al. (2008). Responses of chronically contaminated biofilms to short pulses of diuron: an experimental study simulating flooding events in a small river. Aquat. Toxicol. 87, 252-263. doi: 10.1016/j.aquatox.2008.02.004

Tlili, A., Maréchal, M., Bérard, A., Volat, B., and Montuelle, B. (2011b). Enhanced co-tolerance and co-sensitivity from long-term metal exposures of heterotrophic and autotrophic components of fluvial biofilms. Sci. Total Environ. 409, 4335-4343. doi: 10.1016/j.scitotenv.2011.07.026

Tlili, A., Montuelle, B., Bérard, A., and Bouchez, A. (2011c). Impact of chronic and acute pesticide exposures on periphyton communities. Sci. Total Environ. 409, 2102-2113. doi: 10.1016/j.scitotenv.2011.01.056

Truhaut, R. (1977). Ecotoxicology: objectives, principles and perspectives. Ecotoxicol. Environ. Saf. 1, 151-173. doi: 10.1016/0147-6513(77)90033-1

Tsui, M. T. K., Wang, W.-X., and Chu, L. M. (2005). Influence of glyphosate and its formulation (Roundup ${ }^{\circledR}$ ) on the toxicity and bioavailability of metals to Ceriodaphnia dubia. Environ. Pollut. 138, 59-68. doi: 10.1016/j.envpol.2005.02.018

Vallotton, N., Eggen, R., and Chèvre, N. (2009). Effect of sequential isoproturon pulse exposure on Scenedesmus vacuolatus. Arch. Environ. Contam. Toxicol. 56, 442-449. doi: 10.1007/s00244-008-9200-z

Vallotton, N., Eggen, R. I. L., Escher, B. I., Krayenbühl, J., and Chèvre, N. (2008a). Effect of pulse herbicidal exposure on Scenedesmus vacuolatus: A comparison of two photosystem II inhibitors. Environ. Toxicol. Chem. 27, 1399-1407. doi: 10.1897/07-197

Vallotton, N., Moser, D., Eggen, R. I. L., Junghans, M., and Chèvre, N. (2008b). S-metolachlor pulse exposure on the alga Scenedesmus vacuolatus: Effects during exposure and the subsequent recovery. Chemosphere 73, 395-400. doi: 10.1016/j.chemosphere.2008.05.039

Vermeirssen, E. L., Hollender, J., Bramaz, N., van der Voet, J., Escher, B. I., Vermeirssen, E. L. M., et al. (2010). Linking toxicity in algal and bacterial assays with chemical analysis in passive samplers deployed in 21 treated sewage effluents. Environ. Toxicol. Chem. 29, 2575-2582. doi: 10.1002/e tc. 311

Vermeirssen, E. L. M., Bramaz, N., Hollender, J., Singer, H., and Escher, B. I. (2009). Passive sampling combined with ecotoxicological and chemical analysis of pharmaceuticals and biocides - evaluation of three Chemcatcher ${ }^{\mathrm{TM}}$ configurations. Water Res. 43, 903-914. doi: 10.1016/j.watres.2008. 11.026

Vermeirssen, E. L. M., Dietschweiler, C., Escher, B. I., Van Der Voet, J., and Hollender, J. (2012). Transfer kinetics of polar organic compounds over polyethersulfone membranes in the passive samplers pocis and chemcatcher. Environ. Sci. Technol. 46, 6759-6766. doi: 10.1021/es3007854

Vermeirssen, E. L. M., Körner, O., Schönenberger, R., Suter, M. J. F., and Burkhardt-Holm, P. (2005). Characterization of environmental estrogens in river water using a three pronged approach: active and passive water sampling and the analysis of accumulated estrogens in the bile of caged fish. Environ. Sci. Technol. 39, 8191-8198. doi: 10.1021/es050818q

Vrana, B., Allan, I. J., Greenwood, R., Mills, G. A., Dominiak, E., Svensson, K., et al. (2005). Passive sampling techniques for monitoring pollutants in water. $\operatorname{Tr} A C$ Trends Anal. Chem. 24, 845-868. doi: 10.1016/j.trac.2005.06.006

Wallen, D. G. (1996). Adaptation of the growth of the diatom Fragilaria crotonensis (kitton) and the phytoplankton assemblage of Lake Erie to chromium toxicity. J. Great Lakes Res. 22, 55-62. doi: 10.1016/S03801330(96)70934-6

Zhou, C.-F., Wang, Y.-J., Li, C.-C., Sun, R.-J., Yu, Y.-C., and Zhou, D.-M. (2013). Subacute toxicity of copper and glyphosate and their interaction to earthworm (Eisenia fetida). Environ. Pollut. 180, 71-77. doi: 10.1016/j.envpol.2013. 05.016

Conflict of Interest Statement: The authors declare that the research was conducted in the absence of any commercial or financial relationships that could be construed as a potential conflict of interest.

Copyright (c) 2016 Kim Tiam, Fauvelle, Morin and Mazzella. This is an open-access article distributed under the terms of the Creative Commons Attribution License (CC $B Y)$. The use, distribution or reproduction in other forums is permitted, provided the original author(s) or licensor are credited and that the original publication in this journal is cited, in accordance with accepted academic practice. No use, distribution or reproduction is permitted which does not comply with these terms. 